\title{
New Insights into Diffuse Large B-Cell Lymphoma Pathobiology
}

\author{
Antonio Giovanni Solimando ${ }^{1,2, *} \mathbb{C}$, Tiziana Annese ${ }^{3} \mathbb{D}$, Roberto Tamma ${ }^{3}$, \\ Giuseppe Ingravallo ${ }^{4}{ }^{(}$, Eugenio Maiorano ${ }^{4} \mathbb{D}$, Angelo Vacca ${ }^{1}\left(\mathbb{0}\right.$, Giorgina Specchia ${ }^{5}$ \\ and Domenico Ribatti ${ }^{3, *(1)}$ \\ 1 Department of Biomedical Sciences and Human Oncology, Section of Internal Medicine 'G. Baccelli', \\ University of Bari Medical School, 70124 Bari, Italy; angelo.vacca@uniba.it \\ 2 Istituto di Ricovero e Cura a Carattere Scientifico-IRCCS Istituto Tumori “Giovanni Paolo II" of Bari, \\ 70124 Bari, Italy \\ 3 Department of Basic Medical Sciences, Neurosciences, and Sensory Organs, University of Bari Medical \\ School, 70124 Bari, Italy; tiziana.annese@uniba.it (T.A.); roberto.tamma@uniba.it (R.T.) \\ 4 Department of Emergency and Transplantation, Pathology Section, University of Bari Medical School, \\ 70100 Bari, Italy; giuseppe.ingravallo@uniba.it (G.I.); eugenio.maiorano@uniba.it (E.M.) \\ 5 Department of Emergency and Transplantation, Hematology Section, University of Bari Medical School, \\ 70100 Bari, Italy; giorgina.specchia@uniba.it \\ * Correspondence: antonio.solimando@uniba.it (A.G.S.); domenico.ribatti@uniba.it (D.R.); \\ Tel.: +39-3395626475 (A.G.S.); +39-080.5478326 (D.R.)
}

Received: 16 June 2020; Accepted: 8 July 2020; Published: 11 July 2020

check for updates

\begin{abstract}
Diffuse large B-cell lymphoma (DLBCL) is the most common non-Hodgkin lymphoma (NHL), accounting for about $40 \%$ of all cases of NHL. Analysis of the tumor microenvironment is an important aspect of the assessment of the progression of DLBCL. In this review article, we analyzed the role of different cellular components of the tumor microenvironment, including mast cells, macrophages, and lymphocytes, in the tumor progression of DLBCL. We examined several approaches to confront the available pieces of evidence, whereby three key points emerged. DLBCL is a disease of malignant B cells spreading and accumulating both at nodal and at extranodal sites. In patients with both nodal and extranodal lesions, the subsequent induction of a cancer-friendly environment appears pivotal. The DLBCL cell interaction with mature stromal cells and vessels confers tumor protection and inhibition of immune response while delivering nutrients and oxygen supply. Single cells may also reside and survive in protected niches in the nodal and extranodal sites as a source for residual disease and relapse. This review aims to molecularly and functionally recapitulate the DLBCL-milieu crosstalk, to relate niche and pathological angiogenic constitution and interaction factors to DLBCL progression.
\end{abstract}

Keywords: DLBCL; tumor microenvironment; angiogenesis; cell adhesion mediated drug resistance; tumor progression

\section{Introduction}

Diffuse large B-cell lymphoma (DLBCL) classified by the 2008 World Health Organization (WHO) classification as one of the B-cell lymphomas types is the most common non-Hodgkin B-cell lymphoma (NHL), accounting for about $40 \%$ of all cases of NHL [1]. DLBCL characteristically presents with advanced stage, both in nodal and in extranodal symptomatic disease, with a median age of 60 , representing an important disease holding a practical objective of treatment represented by a curative approach, while minimizing the toxicity profile [2]. Most DLBCLs arise from germinal B cells at different stages of differentiation where recurrent genetic alterations contribute to the molecular pathogenesis of 
the disease [3,4]. The gene expression profiling technique allowed identifying at least two molecular subtypes of DLBCL with different prognoses [5]. The first is the lymphoma derived from normal germinal center $B$ cells (GCB) and the second one is the lymphoma derived from activated B cells $(\mathrm{ABCs})$ that arise from post-germinal center $\mathrm{B}$ cells that are blocked during plasmocytic differentiation. The two subtypes have different oncogenic mechanisms [6].

Specific markers, including CD10, LM02, and BCL6 are expressed in GCB patients who have a better response to conventional chemotherapy, whereas $\mathrm{ABC}$ patients express lower levels of BCL6 and are refractory to chemotherapy $[5,7]$. The $A B C$ type showed constitutive activation of NF- $\mathrm{KB}$ which may be related to the presence of mutations of multiple genes regulating this pathway [8,9]. Constitutively activated STAT3 is correlated with a more advanced clinical stage and overall poor survival in DLBCL $[10,11]$. In ABC DLBCL, the activation of the Janus kinases (JAKs)/STAT3 pathway correlates with autocrine production of intereukin-6 (IL-6) and IL-10, which promotes cancer progression [12,13]. The STAT3 gene is a transcriptional target of BCL6 and is highly expressed and activated in ABC DLBCL and BCL6-negative normal germinal center B cells [12]. Moreover, STAT3 is strongly linked to tumor angiogenesis and metastasis and is related to poor prognosis in different tumors $[14,15]$. Activation of STAT3 contributes to hypoxia-inducible factor 1 alpha (HIF- $1 \alpha$ ) and vascular endothelial growth factor (VEGF) expression in tumor cells, while VEGF in turn activates STAT3 in endothelial cells. Finally, STAT3 inhibits the expression of the anti-angiogenesis transcription factor p53 [16].

In DLBCL, the gene expression signatures "stromal 1" and "stromal 2", related to extracellular matrix and angiogenesis-related genes, respectively, were identified [17]. Fibrosis and myelo-histiocytic infiltration, representing the "stromal 1" signature, correlated with a positive clinical outcome [18], while the "stromal 2" signature, characterized by increased vasculogenic activity, correlated with dismal prognosis in subjects treated with the R-CHOP (rituximab, cyclophosphamide, doxorubicin, vincristine, and prednisone) protocol [17]. Monocytic myeloid-derived suppressor cells and tumor-associated macrophages (TAMs) play a crucial role in the "stromal 2" signature $[19,20]$. Overall, as in other hematological niche addicted malignancies [21-24], the current evidence pinpoints that DLBCL disease progression is a multistep transformation process characterized by a complex vicious cycle between lymphoma cells and the tumor milieu.

Here, we show the latest findings on the disease evolution of DLBCL, by providing a specific focus on the role of new players within the cancer immune microenvironment in order to envision novel theragnostic windows.

\section{Bridging the Gaps between Disease Biology and Clinical Translation: New and Old Tricks in DLBCL Classification}

A correct diagnosis of DLBCL requires, in addition to the availability of qualitatively and quantitatively adequate tissue, a correct application of the most recent classification principles provided by the use of any ancillary diagnostic techniques. In particular, modern histopathological diagnostics of lymphomas requires knowledge and combination of morphological, phenotypic molecular, cytogenetic, and clinical profiling. This methodological approach constitutes the founding principle of the World Health Organization (WHO) and was translated into the "blue book" "WHO Classification of Tumors of the Hematopoietic and Lymphoid Tissues" [1]. Recent progresses in understanding the immunogenetic mechanisms and genetic molecular alterations of hematopoietic and in particular lymphoid neoplasms allowed a pathogenetic approach to the DLBCL taxonomy. Many lymphomas are considered distinct entities, characterized by immunophenotypic profiles and known genetic alterations, identifiable with laboratory techniques now widely used, with good reproducibility. DLBCL parallels the complex NHL biological architecture, being differentiated into the GCB type and the ABC/non-GC type, by means of an immunohistochemical algorithm, which is a distinction that can influence the therapeutic choice $[1,25,26]$. Furthermore, the co-expression of MYC and BCL2 identifies a new prognostic "subset" ("double-expressor" lymphomas) [27]. Although the understanding of the mutation scenario was 
also widened and deepened, the translational relevance in the clinical subset still represents an unmet medical need.

Recently, NGS studies uncovered different profiles of genomic alterations to be relevant in both the GCB and the non-GCB/ABC subtypes [28]. Alteration in histone-lysine $N$-methyltransferase (EZH2), as well as the translocation of BCL2 and GNA13 mutation, is a fundamental molecular fingerprint described in GCB. Conversely, MYD88, CD79a, CARD11, and TNFAIPA3 mutations play a pivotal role in non-GCB/ACB by activating the BCR and NF- $\mathrm{KB}$ pathways [25]. The importance of a subdivision of diffuse large B-cell lymphomas, NOS in the two groups (GCB and non-GCB/ABC), is confirmed. This distinction, with possible therapeutic consequences, can be obtained in routine diagnostics by applying an immunohistochemical algorithm based on a relatively simple and reliable antibody panel (CD10, BCL6, and IRF4/MUM1) [28]. Moreover, among the DLBCL NOS, the immunohistochemical co-expression of MYC and BCL2, deemed biologically and clinically relevant, identifies the category of double-expressor disease, harboring an unfavorable prognostic impact [27].

\subsection{Molecular Pathogenesis: Novel Insights}

Double/triple-hit high-grade B-cell lymphoma (HGBL-DH/TH) constitutes approximately $8 \%$ of DLBCL, harboring MYC, BCL2, and/or BCL6 translocations. Most of them belong to the GCB molecular subgroup and, clinically, despite the generally superior prognosis of GCB DLBCLs, patients with HGBL-DH/TH have a poor outcome [29]. Double-hit lymphomas show a distinct gene expression profile when dissected by RNA-seq. For example, 157 de novo GCB DLBCLs, including 25 HGBL-DH/TH BCL2, were analyzed to define gene expression differences between HGBL-DH/TH BCL2 and other GCB DLBCLs [30]. When RNA-seq was applied to RNA extracted from fresh frozen biopsy samples, 104 genes that were most significantly differentially expressed between HGBL-DH/TH BCL2 and other GCB DLBCLs were identified [30]. Double-hit gene signature-positive (DHITsig-pos) DLBCLs are characterized by a peculiar cell of origin and a distinct mutational landscape, after genetic feature association with DHITsig status. DHITsig-pos tumors were universally positive for CD10 staining, and the majority were MUM1 (IRF4)-negative. CD10+/MUM1- cases were significantly more frequent in DHITsig-pos tumors. Genes associated with the GC intermediate zone had higher expression within the DHITsis-pos tumors. These findings demonstrate that DHITsig-pos tumors are B cells transitioning from the GC dark zone to the GC light zone. Along with the expected enrichment of mutation in MYC and BCL2, mutations of genes involved in chromatin modification (e.g., CREBBP, EZH2, DDX3X, TP53, and KMT2D) were more frequently harbored by DHITsig-pos tumors [30-32]. Specifically, missense mutations in EZH2, DEAD-box helicase 3 X-linked (DDX3X), and lysine methyltransferase 2D (KMT2D), as well as both missense and truncating mutations in CREB-binding protein (CREBBP) and TP53, point toward different clinical features of the corresponding DLBCL subjects [30]. Moreover, DHITsig identified a group of DLBCL with peculiar clinical features. The variable molecular signatures, which identify HGBL and are constituted by the karyotype, the immunohistochemistry, and the DHIT signature [30], uncovered novel clinical scenarios to be driven by a still evolving genomic landscape in DLBCL, and they enable a rational patient management, based on consolidated $[26,33]$ and novel therapeutic approaches $[25,34]$.

In the frame of this thinking, regulation of chromatin status plays a pivotal role in the correct development and differentiation of mature B cells, and it is extensively investigated with therapeutic purposes. In B-cell tumors, a plethora of mutations affect genes involved in chromatin regulation and in normal B-cell development [31-33]. Specifically, EP300 and CREBP are main acetylation regulators and, therefore, modulate gene expression, as well as histone methylators such as KMT2D, SUZ12, and EZH2 [35-37]. These genes are mutated in $25-30 \%$ of DLBCL cases. Notably, CREBBP and EP300 positively modulate multiple biological programs in the germinal center, through acetylation of histone and nonhistone proteins. Moreover, CREBBP and EP300 mutations contribute to lymphomagenesis by perturbing the expression of genes that are relevant to normal biology (i.e., BCL6 and p53). Inactivation of CREBBP and EP300 rarely coexists in human DLBCL, suggesting that cells require a certain amount 
of acetyltransferase activity [38]. Remarkably, GC B cells essentially require a minimum amount of acetyltransferase activity [39] and CREBBP-mutated B cells are addicted to the residual activity of EP300, envisioning potential therapeutic windows driven by CREBBP-mutated GC B cells on EP300 [39]. Thus, double KO of CREBBP and EP300 is required to abrogate GC formation detected by BCL6 immune staining. Furthermore, CREBBP-deficient cells are preferentially sensitive to inhibitors targeting HAT/BRD domains of CREBBP/EP300 [39]. In DLBCL with CREBBP genetic inactivation by mutation, pharmacologic inactivation of EP300 may lead to lymphoma cell death. Additionally, EP300 polymorphism was uncovered to decrease the balance between acetylation and deacetylation in the tumor niche, impacting disease progression [40]. Epigenetic dysregulation can, therefore, represent one of the driver lesions in high-risk DLBCL, and the restoration of physiological chromatin remodeling is an attractive target for novel therapy.

In tumor patients, based on evidence from other solid [41-43] and hematological malignancies [44-47], cell-free DNA (cfDNA) and extracellular vesicles are released by tumor apoptotic cells; DLBCL makes no exception [48,49]. Circulating tumor DNA (ctDNA) is distinguished from other cfDNA by the presence of somatic mutations representative of tumor biology absent in normal cells [50]. Liquid biopsy was employed as a new tool for genotyping and evaluating minimal residual disease in DLBCL [51,52]. Kurtz et al. uncovered ctDNA ${ }^{\text {high }}$ DLBCL to be characterized by a prognostically unfavorable outcome [52]. Remarkably, the non-tumor cfDNA might additionally originate from the neoplastic site, expanding the concept of liquid biopsy to the microenvironment compartment [53]. Liquid biopsy and molecular deconvolution [51], dissecting the genomic architecture of hematological malignancies, are becoming tools able to predict the prognosis $[7,54,55]$.

\subsection{Molecular Prognostic Models}

Efficient clinical prognostic tools were uncovered to be relevant in driving patient management. The international literature highlighted some molecular characteristics of DLBCLs that condition their prognosis and, in perspective, the therapy [1]. Adequate histological diagnosis must include in the report an evaluation of the parameters useful to guide the therapeutic choice in order to confirm the cell of origin, its immunophenotype, the presence of double expressors, and the proliferation index, as well as sometimes specific FISH characteristics addressed by BCL2, BCL6, MYC, and IG-heavy/kappa/lambda (IGH/IGK/IGL) DNA probes $[1,56]$. The prognostic impact of the biological characteristics holds relevant translational consequences. To this end, a proper stratification included specific characteristics of investigation on the cancer cells that were uncovered to be CD20- and/or CD79a-expressing B lymphocytes [26,57]; additionally, anti-CD5 was deemed important when expressed, thus allowing the identification of a clinically more aggressive CD5+ DLBCL subset [57]. Moreover, while characterizing the cell of origin phenotype, CD10, BCL6, and MUM1 play a pivotal role, by driving the GC-type identification, differentiated by CD10 and/or BCL6 expression in $>30 \%$ of DLBCL cells, while their low expression, along with $>30 \%$ expression of MUM1 documentation, indicates a non-GC-type [58].

MYC/BCL2 evaluation in DLBCL using immunohistochemical staining was employed to exactly define double expression and to identify subgroups with dismal prognosis, often belonging to the non-GC-type subgroup [59]. A percentage of cells with intense MYC positivity $>70 \%$ is often associated with translocation [60].

The percentage of Ki67-positive tumor cells (clone MIB1) should also be considered. In the event of uneven distribution in the tissue, it is advisable to report a percentage value representative of the average, while signaling the uneven distribution of the positivity signal [61].

Several alternative prognostic models already exist for DLBCL. A new one was uncovered to be significant, showing, in 199 cases, the relevance of the immunohistochemistry according to the Hans algorithm and MYC/BCL2 evaluation. The cell of origin evaluated by Nanostring, FISH analysis assessing BCL2, BCL6, and c-MYC, and the targeted sequencing from a custom platform based on univariate analysis identifying gene mutations significantly correlated to poor or favorable prognosis [62]. According to that stratification system, the authors elaborated an m3D-IPI uncovering 
sex, age, extranodal sites, LDH, advanced stage, double hit, and mutation in KMT2D, PIM1, and MEF2B as being significantly related to high-risk disease in R-CHOP-treated patients. Despite statistically powered validation studies being required, this novel approach performed better than traditional IPI in this patient cohort (C-index 0.87 vs. 0.77 , respectively). The increasing number of biological acquisitions, combined with clinical characteristics of patients, will allow a better treatment tailoring.

Recently, since limited data are available on comprehensive genetic signatures, Chapuy et al. proposed a novel molecular gene signature deconvoluting the DLBCL heterogeneity. While dissecting the complex genomic architecture, these authors uncovered an integrated approach combining analyses of recurrent mutations, somatic copy number alterations (SCNAs), and structural variants (SVs) to efficiently reveal DLBCL taxonomy, and they highlighted five genetically distinctive clusters (C1-C5) [63]. Specifically, these genetically distinct DLBCL subsets predict different outcomes, provide novel insights into lymphomagenesis, and suggest certain combinations of targeted therapies $[63,64]$. In more detail, among ABC DLBCLs, the C1 subtype DLBCL was deemed to be associated with favorable prognosis and was characterized by MYD ${ }^{\text {non-L265P }}, \mathrm{NOTCH2}$, and SPEN mutations, as well as BCL6 SVs, and this phenotype might origin from marginal-zone lymphoma and from an ancestor of extrafollicular origin [63]. Conversely, C5 subtype DLBCLs correlated with unfavorable clinical outcome, harboring BCL2 ${ }^{\text {gain }}, \mathrm{MYD}^{\mathrm{L}} 8^{\mathrm{L} 265}, \mathrm{CD} 79 \mathrm{~B}^{\mathrm{mut}}$, and TBL1XR1 ${ }^{\text {mut }}$, and they were associated with extranodal tropism and genes overexpressed in the BCL2-overexpressing group [65,66]. Contrariwise, within the GCB DLBCLs, the C4 subtype was associated with more favorable PFS, and it was characterized by mutations in NF-KB, JAK/STAT, and RAS pathway components and histone genes. The $\mathrm{C} 3$ subgroup paralleled the $\mathrm{C} 5$ dismal prognosis, being associated with BCL2 SV and mutations, PTEN CN loss and mutation, and chromatin-modifying enzyme alterations. Lastly, Chapuy et al. also identified a remarkable feature from a C2 subtype with a distinct clinical trajectory, being composed by bi-allelic TP53 inactivation, 9p21.23/CDNKN2A copy loss, and increased genomic instability reflected by recurrent SCNAs and frequent genome doublings [63]. Next, to validate the genetic substrate in an independent dataset and develop a robust molecular classifier allowing prediction in new samples, Chapuy et al. also genetically confirmed identity-associated marker genes and biology of the C1-C5 DLBCL clusters in a combined larger cohort $[32,67]$. This independent analysis sanctioned a parsimonious probabilistic classifier able to prospectively identify the $\mathrm{C} 1-\mathrm{C} 5$ DLBCL subtypes in newly diagnosed patients [67].

\subsection{Tumor Microenvironment and Angiogenesis}

Based on several pieces of compelling evidence highlighting the impact of the DLBCL niche in nursing cancer cells, by promoting a favorable stromal environment, several prospective clinical studies are needed to validate the clinical utility of the stromal gene expression profile in DLBCL and dissect subtypes which would profit the most from anti-angiogenic and milieu-targeting strategies $[68,69]$. Nonetheless, it is well known that the presence of immune and inflammatory cells contributes to modulate tumor growth and invasion in hematological malignancies and DLBCL [70-72]. Analysis of the tumor microenvironment is an important aspect in the assessment of progression of DLBCL. Different components of the microenvironment are considered in DLBCL including mast cells and TAMs to establish several correlations among prognostic significance, stage-related tumor progression, and differences in treatment outcome [73,74].

Lymphomas include more than 40 lymphoproliferative disorders, and angiogenesis plays a critical role in their progression and prognosis $[75,76]$.

The state-of-the-art knowledge of the crucial mechanisms promoting angiogenesis and mediating immunosuppression during DLBCL development, progression [77,78], and sensitivity to drugs [26,79] needs further in-depth analysis. Solid and hematological neoplasms propagate and progress through several vicious cycles, feeding into the surrounding tumoral milieu [80-83], and emergent knowledge pinpoints angiogenesis and immunosuppression as simultaneous processes in response to this reciprocal loop $[84,85]$ and to a plethora of paracrine and exogenous stimuli [86-88]. Lymphoproliferative 
disorders [89,90] and DLBCL [91] are no exception. Accordingly, strategies combining anti-angiogenic therapy and immunotherapy seem to have the potential to tip the balance of the tumor microenvironment and improve the treatment response of lymphoid malignancies [21,22,92,93]. These pieces of evidence prompted an intense translational investigation aimed at targeting angiogenesis and the immune system in a coordinated fashion, based on the preclinical insights available [94,95].

\subsection{Increased Vascularization, VEGF Expression and MicroRNA (miRNA)}

The presence of an increased number of immature vessels in DLBCL compared with follicular lymphoma (FL) was demonstrated [96]. ABC DLBCL CD5+ showed higher microvascular density (MVD) than GCB DLBCL [97]. MVD was higher in CD5+ DLBCL in comparison with the CD5subgroup [98].

Transformation from indolent B-cell lymphoma to aggressive DLBCL and poor prognostic subgroups within DLBCL is associated with increased VEGF expression [99]. In aggressive subtypes of DLBCL, VEGF-A-producing CD68+ VEGFR1+ myelo-monocytic cells are closely associated with newly formed blood vessels [68]. In DLBCL, the average MVD correlates with the intensity of VEGF, VEGFR-1, and VEGFR-2 expression in tumor cells [100]. Other studies in DLBCL found no correlation between MVD and VEGF expression [101]. The transcript level of the soluble isoforms of VEGF, such as VEGF121, has a major impact on the prognosis of ABC-like DLBCL, whereas low VEGF121 expression was associated with a significantly better survival than high expression [91]. Moreover, 57 genes involved in immune response and T-cell activation were decreased in patients with high VEGF121 expression in both ABC-like and GBC-like subtypes of DLBCL [91].

In a meta-analysis of eight studies conducted on 670 patients, positive VEGF expression in blood-circulating lymphocytes and lymph nodes correlated with shorter survival in newly diagnosed DLBCL [102]. In another study performed on 149 newly diagnosed DLBCLs, high serum VEGF level was associated with poorer prognosis [103]. VEGF-A- and VEGFR-1-negative patients had an improved overall survival compared to VEGF-A- and VEGFR-1-positive ones [104]. Polymorphism in the VEGFR-2 gene may be associated with better survival in DLBCL patients [105].

Borges et al. [106] demonstrated an association between increased expression of pro-angio miRs miR-126 and miR130a, along with anti-angio miR-328, and the subtype non-GCB. Moreover, they found higher levels of the anti-angio miR-16, miR-221, and miR-328 in patients with low MVD and a stromal 1 signature.

More recently, Lupino et al. [107] demonstrated that the overexpression of SPHK1, one of the two isozymes responsible for the production of sphingosine-1 phosphate (SP1), a bioactive sphingolipid metabolite acting as a potent inducer of angiogenesis [108], correlates with an angiogenic transcriptional program in DLBCL.

\subsection{Correlations among Angiogenesis, VEGF Expression, and Response to Therapy}

Immunodeficient mice engrafted with human DLBCL treated with antibodies against human or murine VEGFR-1 or VEGFR-2 showed a significant $50 \%$ reduction in tumor mass after treatment with human anti-VEGFR-1. By contrast, inhibition of murine VEGFR-1 resulted in a similar tumor reduction, but inhibition of human VEGFR-2 had no antitumor effect [109].

In patients affected by DLBCL treated with anthracycline-based chemotherapy, no correlation between increased MVD and VEGF expression in tumor cells was demonstrated. Moreover, high VEGF and VEGFR-1 expression identified a subgroup of patients affected by DLBCL with improved overall survival and progression-free survival [100]. In patients with DLBCL treated with R-CHOP, a high serum level of VEGF was associated with adverse outcome, having lower values in survivors than in non-survivors [110]. Additionally, high MVD determines a poor outcome in DLBCL in patients treated with R-CHOP [97]. Bevacizumab inhibits tumor growth, either alone or in combination with chemotherapy, in untreated DLBCL [111]. 


\subsection{Targeting Angiogenesis and the Immune System in DLBCL: A Single-Center Experience}

Recently, we demonstrated that there is a significant increase in tryptase-positive mast cells and CD68-positive TAMs, as well as a significant increase in MVD and a positive correlation in chemo-resistant non-responder when compared with chemo-sensitive responder DLBCL patients (Figure 1) [112].
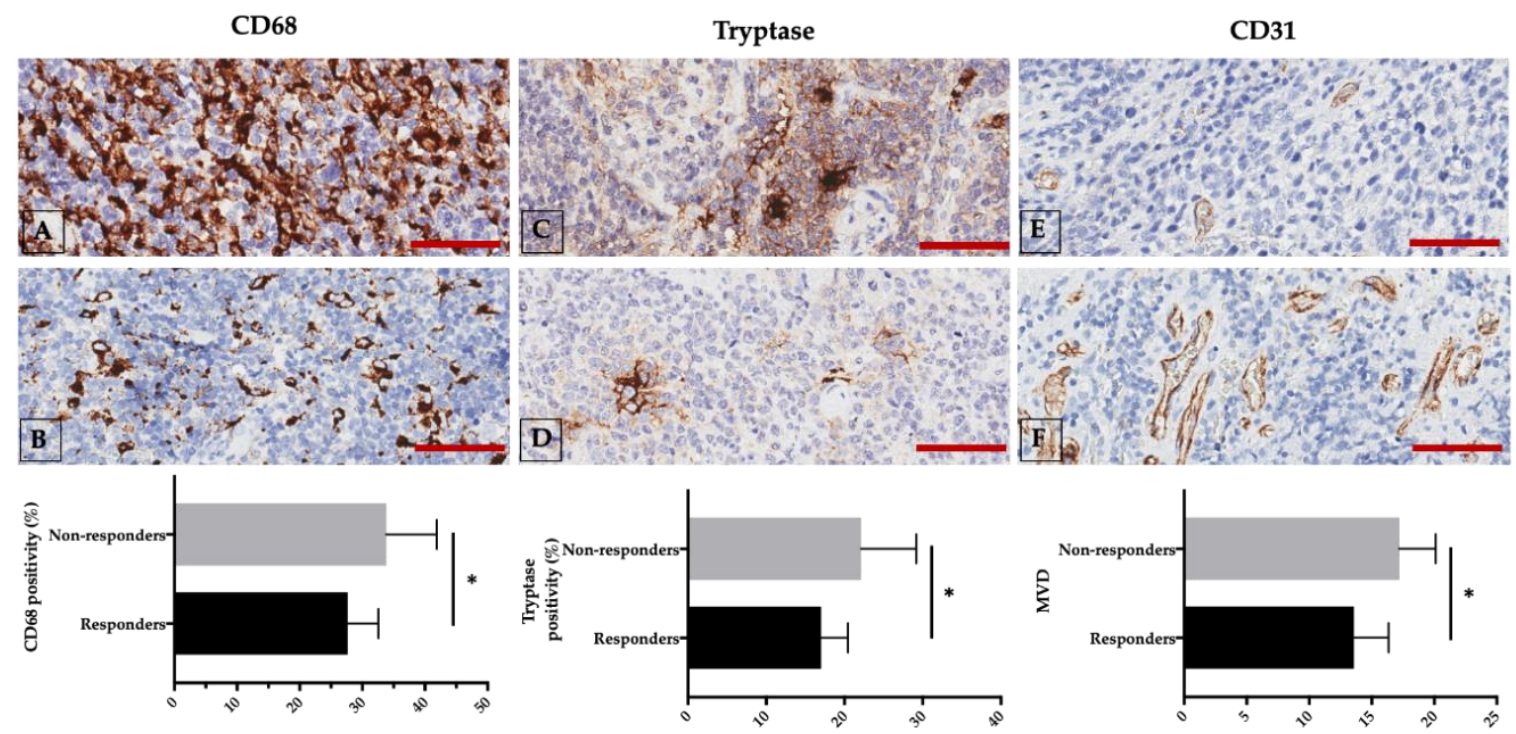

Figure 1. Non-responder (upper panels $(\mathbf{A}, \mathbf{C}, \mathbf{E})$ and responder newly diagnosed diffuse large B-cell lymphoma (DLBCL) patients (middle panels $(\mathbf{B}, \mathbf{D}, \mathbf{F})$ are characterized by different CD68, tryptase, and CD31 expression. Lower panels: respective comparison of non-responder and responder groups. Scale bar: $50 \mu \mathrm{m} .{ }^{*} p<0.05$, assessed by Mann-Whitney test. Representative images from 29 untreated DLBCL patients are presented [112].

Moreover, we uncovered CD3-positive T cells to be decreased while comparing bulky (patients with bulky disease are defined by the presence of a large nodal tumor mass $>10 \mathrm{~cm}$ or mediastinal disease) and non-bulky groups (Figure 2) [113], suggesting that a reduction in T cells in bulky disease patients contributes to loosen the immune control over the tumor, resulting in increased cell proliferation and large tumor masses [114].

Likewise, we demonstrated, comparing by means of RNA scope technology, STAT3 RNA expression in two selected groups of ABC DLBCL and GBC DLCBCL, that ABC tissue samples contained a significantly higher number of STAT3-positive cells than GBC tissue samples (Figure 3) [115].

Furthermore, through microscopic imaging, we uncovered tumor vessels in ABC samples but not GBC samples to be coated by FVIII- and STAT3-positive endothelial cells [115]. Evidence from our group revealed a positive correlation not only between STAT3 expression and CD3, CD8, and CD68, but also between D163-positive cells in the ABC and the GBC groups (Figure 4) [116].

Additionally, in the ABC group, we found also a positive correlation between CD8- and CD34and between Ki67- and CD68/CD163-positive cells (Figure 5). 


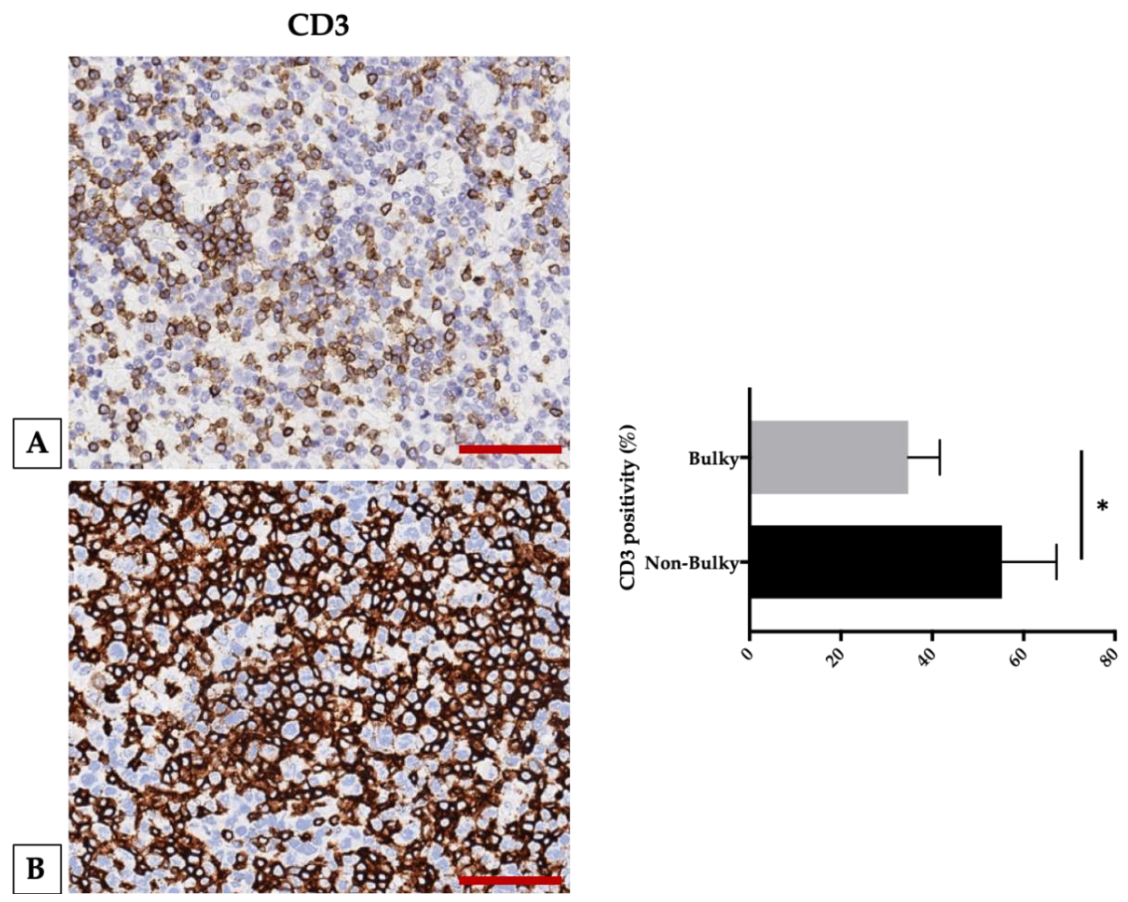

Figure 2. CD3 expression in bulky and non-bulky DLBCL. Left panel: (A) Representative image of CD3 expression in a case with bulky involvement. (B) Representative image of CD3 expression in a case with non-bulky DLBCL. Right panel: comparison between bulky and non-bulky disease groups with a significant difference between the groups in the CD3 infiltrate. Scale bar: $50 \mu \mathrm{m}$. ${ }^{*} p<0.05$, assessed by Mann-Whitney test. Representative images from 29 untreated DLBCL patients are presented [113].

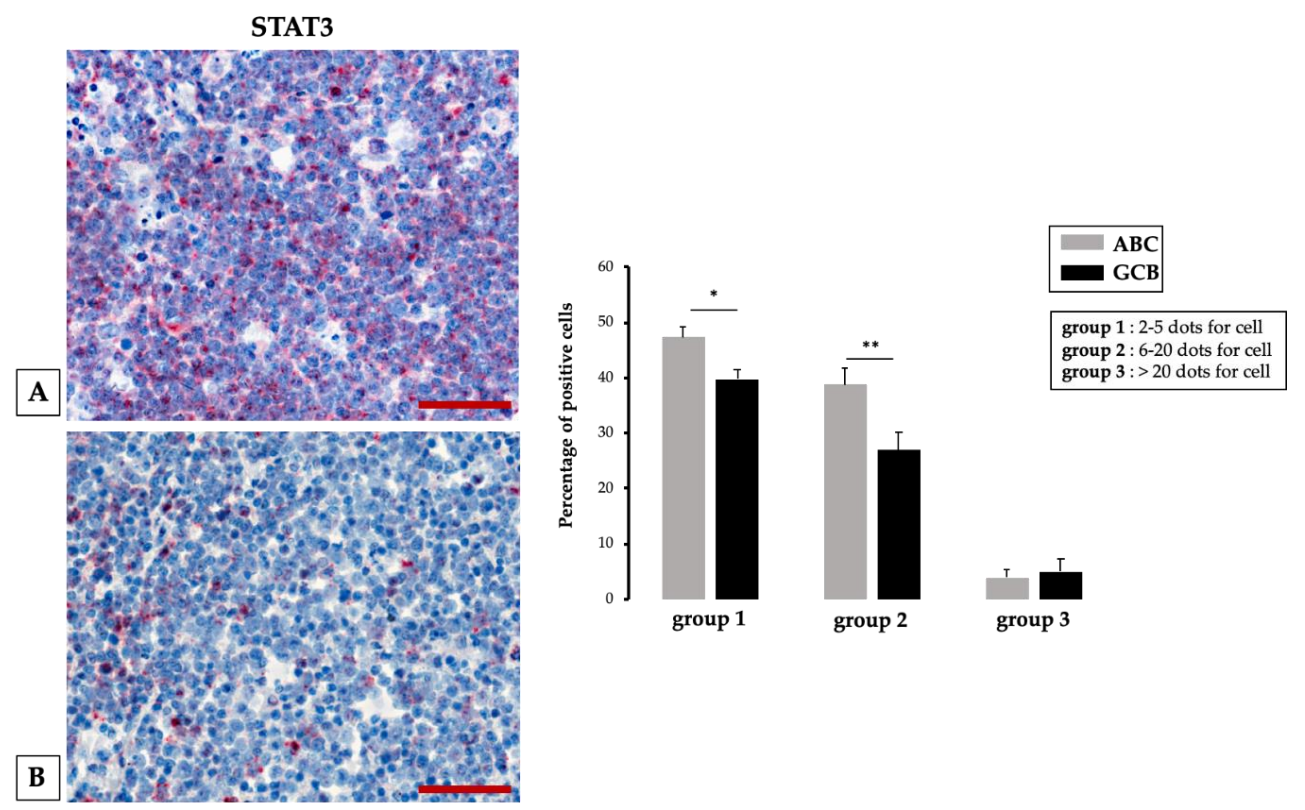

Figure 3. Left panel: different STAT3 expression in histological samples from activated B cell (ABC) (A) and germinal center B cell (GCB) (B) DLBCL assessed by RNAscope. Scale bar: $60 \mu \mathrm{m}$. Right panel: quantification of RNA ISH staining of STAT3 messenger RNA (mRNA) positivity in ABC and GCB DLBCL samples. The percentage of STAT3 mRNA expression significantly increases in the ABC group 1 and 2 tumor samples compared to GCB; ${ }^{*} p<0.05$; ${ }^{* *} p<0.01$, assessed by Mann-Whitney test. Representative images from 30 untreated DLBCL patients are presented [115]. 
CD3
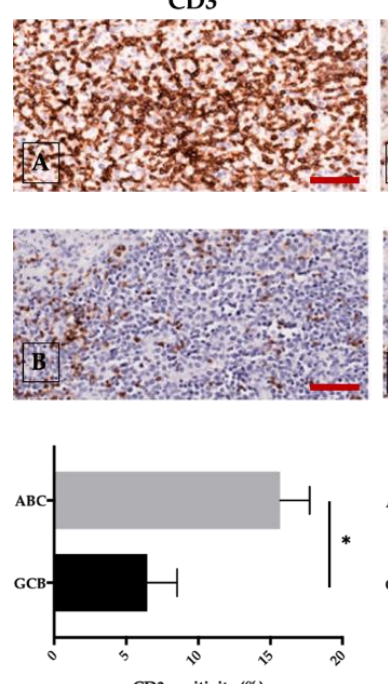

CD3 positivity (\%)
CD8
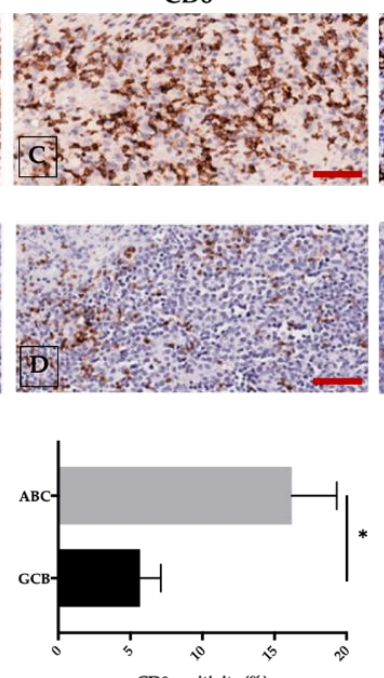

CD68
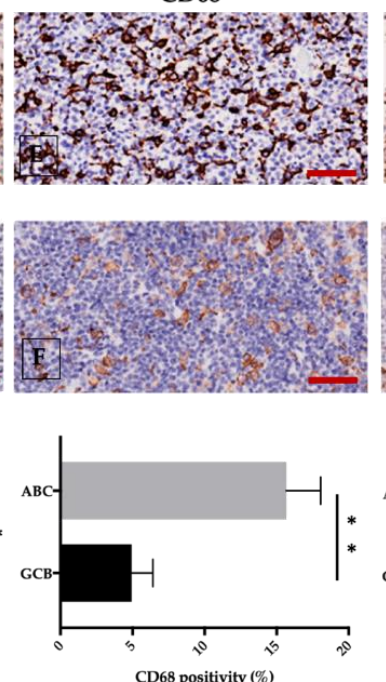

CD163
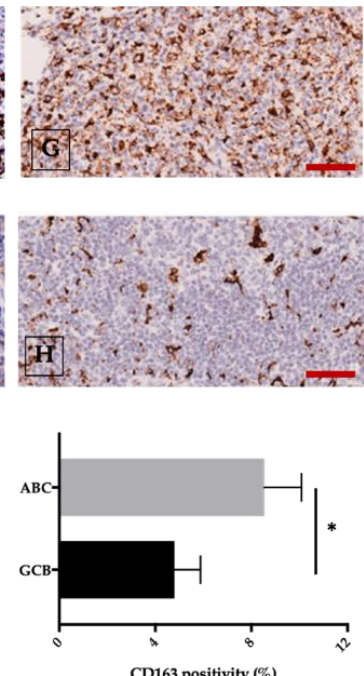

Figure 4. ABC (upper panel) and GCB (middle panel) DLBCL different expression of CD3 (A,B), CD8 (C,D) CD68 (E,F), and CD163 (G,H) assessed by immunohistochemical staining. The morphometric analysis is expressed as marker percentage positivity (lower panel). Scale bar: A-H $60 \mu \mathrm{m}$. Representative images from 60 untreated DLBCL patients are presented; ${ }^{*} p<0.05 ;{ }^{* *} p<0.01$, assessed by Mann-Whitney test [116].
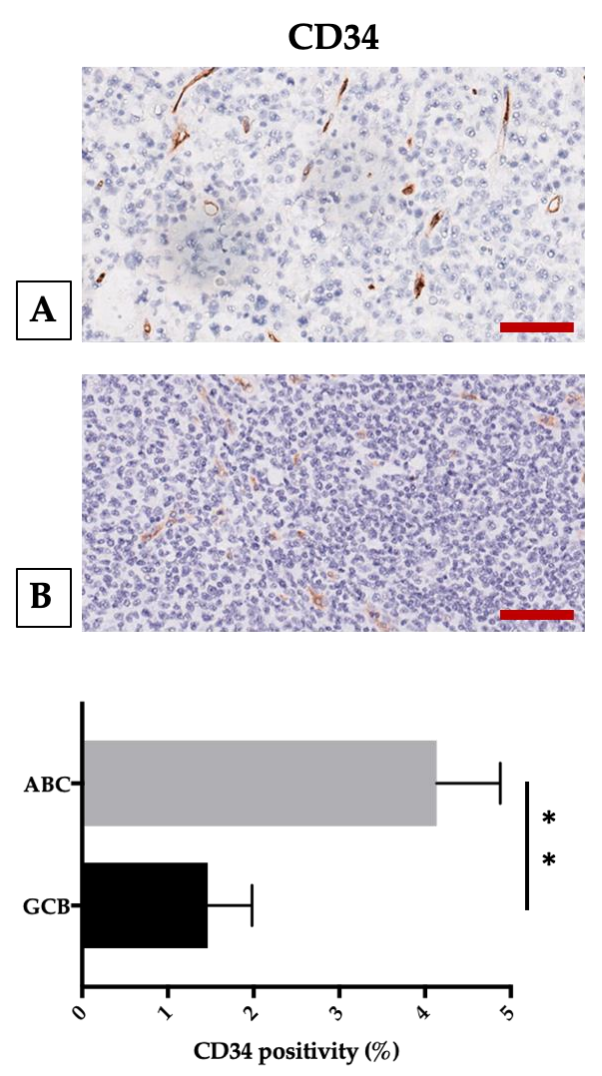
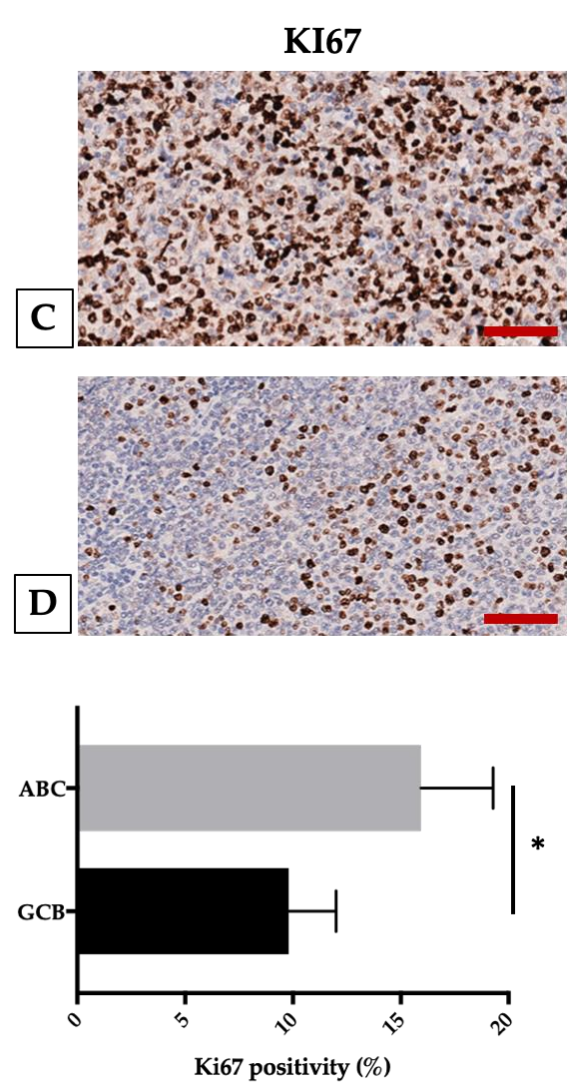

Figure 5. ABC (upper panel) and GCB (middle panel) DLBCL different expression of CD34 (A,B) and Ki67 (C,D) assessed by immunohistochemical staining. The morphometric analysis is expressed as marker percentage positivity (lower panel). Scale bar: A-D $60 \mu \mathrm{m}$. Representative images from 60 untreated DLBCL patients are presented; ${ }^{*} p<0.05 ;{ }^{* *} p<0.01$, assessed by Mann-Whitney test [116]. 


\section{Discussion}

Overall, data generated by our group corroborated previous findings, pointing toward a higher STAT3 expression being associated with higher CD163- and CD8-positive cell infiltration, which induces a strong angiogenic response in ABC DLBCL as compared with GCB DLBCL [116]. Preliminary results generated in our and other labs uncovered enhanced angiogenesis to be a strong regulator of lymphoproliferative disorder prognosis due to direct and indirect activation of cell survival [115-117]. The cell-adhesion-dependent DLBCL milieu interaction nurses DLBCL proliferation, by supporting immune-surveillance evasion [118]. Independent data provided compelling evidence that, in the intimate interaction between stromal cells, the malignant clone creates a permissive immune microenvironment within the lymphoma niche, which starts a vicious cycle hijacking anti-tumor activity [21,119,120]. Mechanistically, endothelial cells, by expressing TIM-3, HB-EGF [120-122], and a plethora of surface and soluble factors, prompt defective immunosurveillance and, in turn, allow for the persistence and proliferation of lymphoid neoplastic cells [123-125], envisioning novel therapeutic windows [126,127]. Moreover, the initial observation that the expression level of the adhesion molecules by the malignant lymphoma cells can predict disease outcome in extranodal DLBCL [128] prompted further investigation, especially in peculiar clinical disease phenotypes, such as DLBCLs involving the central nervous system (CNS) [128]. Remarkably, CNS spreading represents a paradigmatic extranodal localization with peculiar pathobiology involving adhesion molecule deregulated expression [129] and hyperactivation of the angiogenesis fueling pathway [130] along with a truncal genomic signature [131], which can contribute to drug sensitivity and resistance [132-134], as in other malignancies [135-137]. Therefore, given that the aberrant expression of adhesion molecules on bone marrow endothelial cells of patients with lymphoid and myeloid neoplasia was also discovered to predict poor clinical outcome [138-141], it is tempting to speculate a vicious cycle in DLBCL by paralleling the neoplastic cell behavior [128], whereby the described molecular signature [36,142] has more interactions among themselves than what would be expected for a random set of gene-encoding proteins drawn from the genome [143].

Based on these findings and on several pieces of compelling evidence investigating how the deregulated adhesion-mediated system would contribute to more aggressive disease, several attempts uncovered the junctional adhesion molecule role in mediating disease aggressiveness $[141,144,145]$. In line with previous results $[128,146,147]$, preliminary data from our lab demonstrate that direct contact of environmental cells with DLBCL cells would enhance adhesion molecule levels, thus preventing both direct and indirect cell invasiveness and epithelial-mesenchymal transition and extra-nodal dissemination (unpublished data). Even more interesting, the cell adhesion molecule junctional adhesion molecule-A (JAM-A) presents remarkable features [148], whereby it can interact with itself if expressed on two opposing cell types. Furthermore, if JAM-A is shed by a cell, the soluble form of the JAM-A molecule can bind to cell-bound JAM-A, which in turn notably enhances its binding capacity [149-151]. Remarkably, consistently with Peng-Peng Xu et al. [128], JAM-A appears related to extra-nodal involvement in DLBCL, being selectively expressed in those cases. The therapeutic effects of blocking angiogenesis, the endothelial adhesion system, JAM-A, and its cognate shedding regulator ADAM17 were mainly observed in preclinical models but not in patients and, therefore, they must be interpreted with caution [151-155]. In a clinical setting, the adhesion system and neoangiogenesis, along with competent CD8 T cells and dendritic cells, had increased OS and time to progression [99]. Thus, it is likely that invasiveness potential, along with new blood vessel formation (i.e., angiogenesis) within the DLBCL environment, is a recognized hallmark of disease progression, mirroring cancer evasion from T-cell immune surveillance [156]. Endothelial progenitor cell trafficking was uncovered to be implicated in DLBCL progression $[157,158]$, especially in early disease phases $[100,159]$. Several clinical trials in DLBCL tested the effects of angiogenesis-targeting agents, such as bevacizumab, which are used in combination with other agents, including B-cell-targeting agents $[101,160,161]$. Nonetheless, the lack of clinical effect in the randomized study gained by the addition of an anti-angiogenic approach to chemo-immunotherapy involving the tumor milieu might 
be predictive of the response to anti-angiogenesis in DLBCL, being beneficial in DLBCL with a high relative expression of a set of endothelial markers and angiogenic gatekeepers (the "stromal 2" subtype), correlating with enhanced vasculogenesis [17,69]. Furthermore, since compelling evidence pinpoints structural abnormalities in the endothelium as impairing antitumor immunity by forming barriers to immune surveillance [162], the tumor-associated endothelium is currently also described as a caretaker that synchronizes the entrance and egress of the immune cells within the neoplastic niche $[163,164]$. Therefore, while defining DLBCL also based on the quantity and quality of immune cell infiltrates might provide novel rationale to overcome the lack of clinical success gained by angiogenesis-targeting agents so far, identifying the abnormalities in the DLBCL endothelium impairing the crosstalk with adaptive immunity may also be valuable. Targeting these abnormalities can improve the success of immune-based therapies for different cancers, as well as DLBCL, by improving immune-vascular crosstalk for DLBCL, enhancing anti-lymphoma immunotherapy using anti-angiogenesis [165]. Thus, further studies of anti-angiogenic approaches in B-NHL and DLBCL should not be denied [161]. Indeed, while preventing secondary immunodeficiencies [166,167], this evidence provides the translational rationale to overcome the scanty effect of the anti-angiogenic approach in DLBCL obtained so far by novel angiogenesis targeting via RAS pathway inhibition, while combining immune-modulatory agents (IMiDs, i.e., lenalidomide) when appropriate [168-170]. Assuming the different angiogenic impacts on a given disease stage, it would be worth tailoring the vasculogenic manipulation in early DLBCL with the high-risk phenotype [78]. In this frame of thinking, one critical effect of corrupted angiogenesis is represented by disease dissemination, within and outside the original niche localization, driving intra- and extra-nodal adhesion-dependent manifestation in DLBCL. Finally, the judicious use of anti-angiogenics to normalize tumor vasculature might represent a strategy reprograming the tumor microenvironment to improve next-generation immunotherapy for DLBCL.

\section{Conclusions}

Lymphomas constitute a large group of more than 40 lymphoproliferative disorders, classified on the basis of morphologic, immunologic, genetic, and clinical criteria. The importance of the tumor milieu and angiogenesis in lymphoproliferative disorders was studied in relation to their impact on the prognosis of patients, suggesting high relevance in different types of lymphomas. Literature data concerning the angiogenesis of NHL are limited compared with HL, with most studies performed by retrospective immunohistochemical analysis, where evidence of correlation between cellular components of the microenvironment and increased vascularity was established. Within the different types of B-cell lymphomas, angiogenesis may be prominent in aggressive rather than indolent subtypes.

Current frontline DLBCL therapy although fairly successful (70-80\% remission rates with the standard R-CHOP chemotherapy regimen) is frequently followed by relapse (40\% of cases within 2-3 years), with an often refractory DLBCL. Anti-angiogenic therapy and microenvironment-directed therapy represent important tools for the treatment of human lymphomas. However, a significant number of patients are resistant, whereas those who respond have minimal benefits. Nevertheless, these new findings may point toward a potential Achilles heel of DLBCL which, in the future, might be exploited therapeutically in the relapsed/refractory setting and in extranodal dissemination.

Author Contributions: Conceptualization, D.R., A.G.S., G.S., and A.V.; methodology, T.A., R.T., G.I., and E.M.; software, R.T. and A.G.S.; validation, T.A., G.I., and A.V.; formal analysis, A.G.S., R.T., and G.I.; investigation, A.G.S.; resources, A.G.S., D.R., and A.V.; data curation, D.R.; writing-original draft preparation, A.G.S., T.A., and R.T., writing-review and editing, D.R., G.S., and A.V.; visualization, A.G.S., R.T., G.I., and E.M.; supervision, D.R., G.S., and A.V.; project administration, D.R. and A.G.S.; funding acquisition, D.R., A.G.S., G.S., and A.V. All authors read and agreed to the published version of the manuscript.

Funding: This research received no external funding.

Acknowledgments: This work was supported by the Association against Lymphomas "Il Sorriso di Antonio", Corato, Italy. This work was also supported in part by Associazione Italiana per la Ricerca sul Cancro (AIRC, Milan, Italy) through an Investigator Grant (no. 20441) and GLOBALDOC Project-CUP H96J17000160002 approved 
with A.D. n. 9 on 18 January 2017, from Puglia Region, financed under the Action Plan for Cohesion approved with Commission decision C (2016) 1417 of 3 March 2016 to A.G.S., as well as the Apulian Regional project: medicina di precisione to A.G.S.

Conflicts of Interest: The authors declare no conflict of interest.

\section{Abbreviations}

\begin{tabular}{|c|c|}
\hline ADAM17 & Disintegrin and metalloproteinase domain-containing protein 17 \\
\hline BCL2 & B-Cell CLL/Lymphoma 2 \\
\hline BCL6 & B-Cell Lymphoma 6 Protein \\
\hline $\mathrm{BCR}$ & B-Cell Receptor \\
\hline BRD & Bromodomain \\
\hline CARD11 & Caspase Recruitment Domain Family Member 11 \\
\hline CD68 & cluster of differentiation 68 \\
\hline $\mathrm{CN}$ & Copy number \\
\hline CREB & cAMP-response element-binding protein \\
\hline CREBBP & CREB Binding Protein \\
\hline DDX3X & DEAD-Box Helicase 3 X-Linked \\
\hline DEAD & DEAD-box helicase family \\
\hline $\mathrm{EZH} 2$ & Enhancer Of Zeste Homolog 2 \\
\hline FISH & Fluorescence in situ hybridization \\
\hline FVIII & Factor VIII \\
\hline GNA13 & G Protein Subunit Alpha 13 \\
\hline HAT & Histone Acetyltransferase \\
\hline HB-EGF & Heparin-binding EGF-like growth factor \\
\hline $\operatorname{Ig}$ & Immunoglobulin \\
\hline IRF4 & interferon regulatory factors 4 \\
\hline ISH & In situ hybridization \\
\hline KMT2D & Lysine Methyltransferase 2D \\
\hline $\mathrm{KO}$ & Knock out \\
\hline LMO2 & LIM domain only 2 (rhombotin-like 1 ) \\
\hline m3D-IPI) & three-risk group model International Prognostic Index \\
\hline MIB1 & Mindbomb E3 Ubiquitin Protein Ligase 1 \\
\hline MUM1 & melanoma associated antigen (mutated) 1 \\
\hline MYC & Myc-Related Translation/Localization Regulatory Factor \\
\hline MYD & Myeloid Differentiation Primary Response Gene \\
\hline MYD88 & Myeloid Differentiation Primary Response Gene (88) \\
\hline NF- $k B$ & Nuclear Factor Kappa B Subunit \\
\hline NGS & next generation sequensing \\
\hline NOS & nitric oxide synthase \\
\hline NOTCH2 & Neurogenic Locus Notch Homolog Protein 2 \\
\hline OS & Overall Survival \\
\hline PFS & Progressiob free Survival \\
\hline PTEN & Phosphatase And Tensin Homolog \\
\hline RAS & Rat Sarcoma Viral Oncogene Homolog \\
\hline SPEN & SPEN family transcriptional repressor ( \\
\hline SPHK1 & Sphingosine Kinase 1 \\
\hline STAT3 & Signal Transducer And Activator Of Transcription 3 \\
\hline SUZ12 & Suppressor Of Zeste 12 Protein Homolog \\
\hline TIM-3 & T-cell immunoglobulin mucin-3 \\
\hline TNFAIP3 & Tumor necrosis factor, alpha-induced protein 3 \\
\hline TP53 & Tumor Protein P53 \\
\hline
\end{tabular}




\section{References}

1. WHO. WHO Classification of Tumours of Haematopoietic and Lymphoid Tissues, Revised 4th ed.; Swerdlow, S.H., Campo, E., Harris, N.L., Jaffe, E.S., Pileri, S.A., Stein, H., Thiele, J., Eds.; World Health Organization Classification of Tumours; International Agency for Research on Cancer: Lyon, France, 2017; ISBN 978-92-832-4494-3.

2. Liu, Y.; Barta, S.K. Diffuse large B-cell lymphoma: 2019 update on diagnosis, risk stratification, and treatment. Am. J. Hematol. 2019, 94, 604-616. [CrossRef]

3. Schneider, C.; Pasqualucci, L.; Dalla-Favera, R. Molecular pathogenesis of diffuse large B-cell lymphoma. Semin. Diagn. Pathol. 2011, 28, 167-177. [CrossRef] [PubMed]

4. Miao, Y.; Medeiros, L.J.; Li, Y.; Li, J.; Young, K.H. Genetic alterations and their clinical implications in DLBCL. Nat. Rev. Clin. Oncol. 2019, 16, 634-652. [CrossRef] [PubMed]

5. Alizadeh, A.A.; Eisen, M.B.; Davis, R.E.; Ma, C.; Lossos, I.S.; Rosenwald, A.; Boldrick, J.C.; Sabet, H.; Tran, T.; $\mathrm{Yu}, \mathrm{X}$.; et al. Distinct types of diffuse large B-cell lymphoma identified by gene expression profiling. Nature 2000, 403, 503-511. [CrossRef] [PubMed]

6. Dunleavy, K.; Pittaluga, S.; Czuczman, M.S.; Dave, S.S.; Wright, G.; Grant, N.; Shovlin, M.; Jaffe, E.S.; Janik, J.E.; Staudt, L.M.; et al. Differential efficacy of bortezomib plus chemotherapy within molecular subtypes of diffuse large B-cell lymphoma. Blood 2009, 113, 6069-6076. [CrossRef]

7. Rosenwald, A.; Wright, G.; Chan, W.C.; Connors, J.M.; Campo, E.; Fisher, R.I.; Gascoyne, R.D.; Muller-Hermelink, H.K.; Smeland, E.B.; Giltnane, J.M.; et al. The Use of Molecular Profiling to Predict Survival after Chemotherapy for Diffuse Large-B-Cell Lymphoma. N. Engl. J. Med. 2002, 346, 1937-1947. [CrossRef]

8. Davis, R.E.; Brown, K.D.; Siebenlist, U.; Staudt, L.M. Constitutive Nuclear Factor кB Activity Is Required for Survival of Activated B Cell-like Diffuse Large B Cell Lymphoma Cells. J. Exp. Med. 2001, 194, 1861-1874. [CrossRef]

9. Compagno, M.; Lim, W.K.; Grunn, A.; Nandula, S.V.; Brahmachary, M.; Shen, Q.; Bertoni, F.; Ponzoni, M.; Scandurra, M.; Califano, A.; et al. Mutations of multiple genes cause deregulation of NF- $k \mathrm{~B}$ in diffuse large B-cell lymphoma. Nature 2009, 459, 717-721. [CrossRef]

10. Zl, W.; Yq, S.; Yf, S.; Zhu, J. High nuclear expression of STAT3 is associated with unfavorable prognosis in diffuse large B-cell lymphoma. J. Hematol. Oncol. J. Hematol. Oncol. 2011, 4, 31. [CrossRef] [PubMed]

11. Ok, C.Y.; Chen, J.; Xu-Monette, Z.Y.; Tzankov, A.; Manyam, G.C.; Li, L.; Visco, C.; Montes-Moreno, S.; Dybkaer, K.; Chiu, A.; et al. Clinical Implications of Phosphorylated STAT3 Expression in De Novo Diffuse Large B-cell Lymphoma. Clin. Cancer Res. 2014, 20, 5113-5123. [CrossRef]

12. Ding, B.B.; Yu, J.J.; Yu, R.Y.-L.; Mendez, L.M.; Shaknovich, R.; Zhang, Y.; Cattoretti, G.; Ye, B.H. Constitutively activated STAT3 promotes cell proliferation and survival in the activated B-cell subtype of diffuse large B-cell lymphomas. Blood 2008, 111, 1515-1523. [CrossRef]

13. Lam, L.T.; Wright, G.; Davis, R.E.; Lenz, G.; Farinha, P.; Dang, L.; Chan, J.W.; Rosenwald, A.; Gascoyne, R.D.; Staudt, L.M. Cooperative signaling through the signal transducer and activator of transcription 3 and nuclear factor-kB pathways in subtypes of diffuse large B-cell lymphoma. Blood 2008, 111, 3701-3713. [CrossRef] [PubMed]

14. Yu, H.; Kortylewski, M.; Pardoll, D. Crosstalk between cancer and immune cells: Role of STAT3 in the tumour microenvironment. Nat. Rev. Immunol. 2007, 7, 41-51. [CrossRef] [PubMed]

15. Doucette, T.A.; Kong, L.-Y.; Yang, Y.; Ferguson, S.D.; Yang, J.; Wei, J.; Qiao, W.; Fuller, G.N.; Bhat, K.P.; Aldape, K.; et al. Signal transducer and activator of transcription 3 promotes angiogenesis and drives malignant progression in glioma. Neuro-Oncology 2012, 14, 1136-1145. [CrossRef] [PubMed]

16. Gao, P.; Niu, N.; Wei, T.; Tozawa, H.; Chen, X.; Zhang, C.; Zhang, J.; Wada, Y.; Kapron, C.M.; Liu, J. The roles of signal transducer and activator of transcription factor 3 in tumor angiogenesis. Oncotarget 2017, 8. [CrossRef] [PubMed]

17. Lenz, G.; Wright, G.; Dave, S.S.; Xiao, W.; Powell, J.; Zhao, H.; Xu, W.; Tan, B.; Goldschmidt, N.; Iqbal, J.; et al. Stromal Gene Signatures in Large-B-Cell Lymphomas. N. Engl. J. Med. 2008, 359, 2313-2323. [CrossRef]

18. Sehn, L.H.; Gascoyne, R.D. Diffuse large B-cell lymphoma: Optimizing outcome in the context of clinical and biologic heterogeneity. Blood 2015, 125, 22-32. [CrossRef] 
19. Azzaoui, I.; Uhel, F.; Rossille, D.; Pangault, C.; Dulong, J.; Le Priol, J.; Lamy, T.; Houot, R.; Le Gouill, S.; Cartron, G.; et al. T-cell defect in diffuse large B-cell lymphomas involves expansion of myeloid-derived suppressor cells. Blood 2016, 128, 1081-1092. [CrossRef]

20. Ji, H.; Niu, X.; Yin, L.; Wang, Y.; Huang, L.; Xuan, Q.; Li, L.; Zhang, H.; Li, J.; Yang, Y.; et al. Ratio of Immune Response to Tumor Burden Predicts Survival Via Regulating Functions of Lymphocytes and Monocytes in Diffuse Large B-Cell Lymphoma. Cell. Physiol. Biochem. 2018, 45, 951-961. [CrossRef]

21. Rudelius, M.; Rosenfeldt, M.T.; Leich, E.; Rauert-Wunderlich, H.; Solimando, A.G.; Beilhack, A.; Ott, G.; Rosenwald, A. Inhibition of focal adhesion kinase overcomes resistance of mantle cell lymphoma to ibrutinib in the bone marrow microenvironment. Haematologica 2018, 103, 116-125. [CrossRef]

22. Solimando, A.G.; Da Vià, M.C.; Leone, P.; Borrelli, P.; Croci, G.A.; Tabares, P.; Brandl, A.; Di Lernia, G.; Bianchi, F.P.; Tafuri, S.; et al. Halting the vicious cycle within the multiple myeloma ecosystem: Blocking JAM-A on bone marrow endothelial cells restores the angiogenic homeostasis and suppresses tumor progression. Haematologica 2020. [CrossRef] [PubMed]

23. Solimando, A.G.; Vacca, A.; Ribatti, D. A Comprehensive Biological and Clinical Perspective Can Drive a Patient-Tailored Approach to Multiple Myeloma: Bridging the Gaps between the Plasma Cell and the Neoplastic Niche. J. Oncol. 2020, 2020, 1-16. [CrossRef]

24. Plaks, V.; Kong, N.; Werb, Z. The cancer stem cell niche: How essential is the niche in regulating stemness of tumor cells? Cell Stem Cell 2015, 16, 225-238. [CrossRef]

25. Tilly, H.; Gomes da Silva, M.; Vitolo, U.; Jack, A.; Meignan, M.; Lopez-Guillermo, A.; Walewski, J.; André, M.; Johnson, P.W.; Pfreundschuh, M.; et al. Diffuse large B-cell lymphoma (DLBCL): ESMO Clinical Practice Guidelines for diagnosis, treatment and follow-up. Ann. Oncol. 2015, 26, v116-v125. [CrossRef] [PubMed]

26. Solimando, A.G.; Ribatti, D.; Vacca, A.; Einsele, H. Targeting B-cell non Hodgkin lymphoma: New and old tricks. Leuk. Res. 2016, 42, 93-104. [CrossRef] [PubMed]

27. Reagan, P.M.; Davies, A. Current treatment of double hit and double expressor lymphoma. Hematol. Am. Soc. Hematol. Educ. Program 2017, 2017, 295-297. [CrossRef] [PubMed]

28. Hans, C.P.; Weisenburger, D.D.; Greiner, T.C.; Gascoyne, R.D.; Delabie, J.; Ott, G.; Müller-Hermelink, H.K.; Campo, E.; Braziel, R.M.; Jaffe, E.S.; et al. Confirmation of the molecular classification of diffuse large B-cell lymphoma by immunohistochemistry using a tissue microarray. Blood 2004, 103, 275-282. [CrossRef]

29. Huang, W.; Medeiros, L.J.; Lin, P.; Wang, W.; Tang, G.; Khoury, J.; Konoplev, S.; Yin, C.C.; Xu, J.; Oki, Y.; et al. MYC/BCL2/BCL6 triple hit lymphoma: A study of 40 patients with a comparison to MYC/BCL2 and MYC/BCL6 double hit lymphomas. Mod. Pathol. Off. J. U. S. Can. Acad. Pathol. Inc. 2018, 31, 1470-1478. [CrossRef]

30. Ennishi, D.; Jiang, A.; Boyle, M.; Collinge, B.; Grande, B.M.; Ben-Neriah, S.; Rushton, C.; Tang, J.; Thomas, N.; Slack, G.W.; et al. Double-Hit Gene Expression Signature Defines a Distinct Subgroup of Germinal Center B-Cell-Like Diffuse Large B-Cell Lymphoma. J. Clin. Oncol. Off. J. Am. Soc. Clin. Oncol. 2019, 37, 190-201. [CrossRef]

31. Reddy, A.; Zhang, J.; Davis, N.S.; Moffitt, A.B.; Love, C.L.; Waldrop, A.; Leppa, S.; Pasanen, A.; Meriranta, L.; Karjalainen-Lindsberg, M.-L.; et al. Genetic and Functional Drivers of Diffuse Large B Cell Lymphoma. Cell 2017, 171, 481-494.e15. [CrossRef]

32. Schmitz, R.; Wright, G.W.; Huang, D.W.; Johnson, C.A.; Phelan, J.D.; Wang, J.Q.; Roulland, S.; Kasbekar, M.; Young, R.M.; Shaffer, A.L.; et al. Genetics and Pathogenesis of Diffuse Large B-Cell Lymphoma. N. Engl. J. Med. 2018, 378, 1396-1407. [CrossRef] [PubMed]

33. Cheah, C.Y.; Fowler, N.H.; Wang, M.L. Breakthrough therapies in B-cell non-Hodgkin lymphoma. Ann. Oncol. 2016, 27, 778-787. [CrossRef] [PubMed]

34. Ayyappan, S.; Maddocks, K. Novel and emerging therapies for B cell lymphoma. J. Hematol. Oncol. J. Hematol. Oncol. 2019, 12, 82. [CrossRef] [PubMed]

35. Pasqualucci, L.; Dominguez-Sola, D.; Chiarenza, A.; Fabbri, G.; Grunn, A.; Trifonov, V.; Kasper, L.H.; Lerach, S.; Tang, H.; Ma, J.; et al. Inactivating mutations of acetyltransferase genes in B-cell lymphoma. Nature 2011, 471, 189-195. [CrossRef] [PubMed]

36. Pasqualucci, L.; Trifonov, V.; Fabbri, G.; Ma, J.; Rossi, D.; Chiarenza, A.; Wells, V.A.; Grunn, A.; Messina, M.; Elliot, O.; et al. Analysis of the coding genome of diffuse large B-cell lymphoma. Nat. Genet. 2011, 43, 830-837. [CrossRef] [PubMed] 
37. Morin, R.D.; Mendez-Lago, M.; Mungall, A.J.; Goya, R.; Mungall, K.L.; Corbett, R.D.; Johnson, N.A.; Severson, T.M.; Chiu, R.; Field, M.; et al. Frequent mutation of histone-modifying genes in non-Hodgkin lymphoma. Nature 2011, 476, 298-303. [CrossRef]

38. Pasqualucci, L.; Dalla-Favera, R. Genetics of diffuse large B-cell lymphoma. Blood 2018, 131, $2307-2319$. [CrossRef]

39. Meyer, S.N.; Scuoppo, C.; Vlasevska, S.; Bal, E.; Holmes, A.B.; Holloman, M.; Garcia-Ibanez, L.; Nataraj, S.; Duval, R.; Vantrimpont, T.; et al. Unique and Shared Epigenetic Programs of the CREBBP and EP300 Acetyltransferases in Germinal Center B Cells Reveal Targetable Dependencies in Lymphoma. Immunity 2019, 51, 535-547.e9. [CrossRef]

40. Li, J.; Ding, N.; Wang, X.; Mi, L.; Ping, L.; Jin, X.; Liu, Y.; Ying, Z.; Xie, Y.; Liu, W.; et al. EP300 single nucleotide polymorphism rs20551 correlates with prolonged overall survival in diffuse large B cell lymphoma patients treated with R-CHOP. Cancer Cell Int. 2017, 17, 70. [CrossRef]

41. Crowley, E.; Di Nicolantonio, F.; Loupakis, F.; Bardelli, A. Liquid biopsy: Monitoring cancer-genetics in the blood. Nat. Rev. Clin. Oncol. 2013, 10, 472-484. [CrossRef]

42. Russano, M.; Napolitano, A.; Ribelli, G.; Iuliani, M.; Simonetti, S.; Citarella, F.; Pantano, F.; Dell'Aquila, E.; Anesi, C.; Silvestris, N.; et al. Liquid biopsy and tumor heterogeneity in metastatic solid tumors: The potentiality of blood samples. J. Exp. Clin. Cancer Res. CR 2020, 39, 95. [CrossRef] [PubMed]

43. Krebs, M.; Solimando, A.G.; Kalogirou, C.; Marquardt, A.; Frank, T.; Sokolakis, I.; Hatzichristodoulou, G.; Kneitz, S.; Bargou, R.; Kübler, H.; et al. miR-221-3p Regulates VEGFR2 Expression in High-Risk Prostate Cancer and Represents an Escape Mechanism from Sunitinib In Vitro. J. Clin. Med. 2020, 9, 670. [CrossRef]

44. Pantel, K.; Alix-Panabières, C. Liquid biopsy and minimal residual disease - latest advances and implications for cure. Nat. Rev. Clin. Oncol. 2019, 16, 409-424. [CrossRef] [PubMed]

45. Desantis, V.; Saltarella, I.; Lamanuzzi, A.; Melaccio, A.; Solimando, A.G.; Mariggiò, M.A.; Racanelli, V.; Paradiso, A.; Vacca, A.; Frassanito, M.A. MicroRNAs-Based Nano-Strategies as New Therapeutic Approach in Multiple Myeloma to Overcome Disease Progression and Drug Resistance. Int. J. Mol. Sci. 2020, 21, 3084. [CrossRef]

46. Di Lernia, G.; Leone, P.; Solimando, A.G.; Buonavoglia, A.; Saltarella, I.; Ria, R.; Ditonno, P.; Silvestris, N.; Crudele, L.; Vacca, A.; et al. Bortezomib Treatment Modulates Autophagy in Multiple Myeloma. J. Clin. Med. 2020, 9, 552. [CrossRef] [PubMed]

47. Leone, P.; Buonavoglia, A.; Fasano, R.; Solimando, A.G.; De Re, V.; Cicco, S.; Vacca, A.; Racanelli, V. Insights into the Regulation of Tumor Angiogenesis by Micro-RNAs. J. Clin. Med. 2019, 8, 2030. [CrossRef]

48. Larrabeiti-Etxebarria, A.; Lopez-Santillan, M.; Santos-Zorrozua, B.; Lopez-Lopez, E.; Garcia-Orad, A. Systematic Review of the Potential of MicroRNAs in Diffuse Large B Cell Lymphoma. Cancers 2019, 11, 144. [CrossRef]

49. Hutchinson, L. CtDNA-Identifying cancer before it is clinically detectable. Nat. Rev. Clin. Oncol. 2015, 12, 372. [CrossRef]

50. Snyder, M.W.; Kircher, M.; Hill, A.J.; Daza, R.M.; Shendure, J. Cell-free DNA Comprises an In Vivo Nucleosome Footprint that Informs Its Tissues-Of-Origin. Cell 2016, 164, 57-68. [CrossRef]

51. Rossi, D.; Diop, F.; Spaccarotella, E.; Monti, S.; Zanni, M.; Rasi, S.; Deambrogi, C.; Spina, V.; Bruscaggin, A.; Favini, C.; et al. Diffuse large B-cell lymphoma genotyping on the liquid biopsy. Blood 2017, 129, 1947-1957. [CrossRef]

52. Kurtz, D.M.; Scherer, F.; Jin, M.C.; Soo, J.; Craig, A.F.M.; Esfahani, M.S.; Chabon, J.J.; Stehr, H.; Liu, C.L.; Tibshirani, R.; et al. Circulating Tumor DNA Measurements As Early Outcome Predictors in Diffuse Large B-Cell Lymphoma. J. Clin. Oncol. Off. J. Am. Soc. Clin. Oncol. 2018, 36, 2845-2853. [CrossRef] [PubMed]

53. Diehl, F.; Schmidt, K.; Choti, M.A.; Romans, K.; Goodman, S.; Li, M.; Thornton, K.; Agrawal, N.; Sokoll, L.; Szabo, S.A.; et al. Circulating mutant DNA to assess tumor dynamics. Nat. Med. 2008, 14, 985-990. [CrossRef]

54. Pasqualucci, L.; Dalla-Favera, R. The genetic landscape of diffuse large B-cell lymphoma. Semin. Hematol. 2015, 52, 67-76. [CrossRef] [PubMed]

55. Solimando, A.G.; Da Vià, M.C.; Cicco, S.; Leone, P.; Di Lernia, G.; Giannico, D.; Desantis, V.; Frassanito, M.A.; Morizio, A.; Delgado Tascon, J.; et al. High-Risk Multiple Myeloma: Integrated Clinical and Omics Approach Dissects the Neoplastic Clone and the Tumor Microenvironment. J. Clin. Med. 2019, 8, 997. [CrossRef] [PubMed] 
56. Ventura, R.A.; Martin-Subero, J.I.; Jones, M.; McParland, J.; Gesk, S.; Mason, D.Y.; Siebert, R. FISH analysis for the detection of lymphoma-associated chromosomal abnormalities in routine paraffin-embedded tissue. J. Mol. Diagn. JMD 2006, 8, 141-151. [CrossRef] [PubMed]

57. Dargent, J.-L.; Lespagnard, L.; Feoli, F.; Debusscher, L.; Greuse, M.; Bron, D. De novo CD5-positive diffuse large B-cell lymphoma of the skin arising in chronic limb lymphedema. Leuk. Lymphoma 2005, 46, 775-780. [CrossRef] [PubMed]

58. Lu, T.-X.; Miao, Y.; Wu, J.-Z.; Gong, Q.-X.; Liang, J.-H.; Wang, Z.; Wang, L.; Fan, L.; Hua, D.; Chen, Y.-Y.; et al. The distinct clinical features and prognosis of the $\mathrm{CD} 10^{+} \mathrm{MUM} 1^{+}$and $\mathrm{CD} 10^{-} \mathrm{Bcl6}^{-} \mathrm{MUM}^{-}$diffuse large B-cell lymphoma. Sci. Rep. 2016, 6, 20465. [CrossRef]

59. Hu, S.; Xu-Monette, Z.Y.; Tzankov, A.; Green, T.; Wu, L.; Balasubramanyam, A.; Liu, W.; Visco, C.; Li, Y.; Miranda, R.N.; et al. MYC/BCL2 protein coexpression contributes to the inferior survival of activated B-cell subtype of diffuse large B-cell lymphoma and demonstrates high-risk gene expression signatures: A report from The International DLBCL Rituximab-CHOP Consortium Program. Blood 2013, 121, 4021-4031. [CrossRef]

60. Swerdlow, S.H. Diagnosis of "double hit" diffuse large B-cell lymphoma and B-cell lymphoma, unclassifiable, with features intermediate between DLBCL and Burkitt lymphoma: When and how, FISH versus IHC. Hematol. Am. Soc. Hematol. Educ. Program 2014, 2014, 90-99. [CrossRef]

61. Hasselblom, S.; Ridell, B.; Sigurdardottir, M.; Hansson, U.; Nilsson-Ehle, H.; Andersson, P.-O. Low rather than high Ki-67 protein expression is an adverse prognostic factor in diffuse large B-cell lymphoma. Leuk. Lymphoma 2008, 49, 1501-1509. [CrossRef]

62. Song, J.Y.; Perry, A.M.; Herrera, A.F.; Chen, L.; Skrabek, P.; Nasr, M.; Ottesen, R.; Nikowitz, J.; Bedell, V.; Murata-Collins, J.; et al. New Genomic Model Integrating Clinical Factors and Gene Mutations to Predict Overall Survival in Patients with Diffuse Large B-Cell Lymphoma Treated with R-CHOP. Blood 2018, 132, 346. [CrossRef]

63. Chapuy, B.; Stewart, C.; Dunford, A.J.; Kim, J.; Kamburov, A.; Redd, R.A.; Lawrence, M.S.; Roemer, M.G.M.; Li, A.J.; Ziepert, M.; et al. Molecular subtypes of diffuse large B cell lymphoma are associated with distinct pathogenic mechanisms and outcomes. Nat. Med. 2018, 24, 679-690. [CrossRef] [PubMed]

64. Bojarczuk, K.; Wienand, K.; Ryan, J.A.; Chen, L.; Villalobos-Ortiz, M.; Mandato, E.; Stachura, J.; Letai, A.; Lawton, L.N.; Chapuy, B.; et al. Targeted inhibition of PI3K $\alpha / \delta$ is synergistic with BCL-2 blockade in genetically defined subtypes of DLBCL. Blood 2019, 133, 70-80. [CrossRef] [PubMed]

65. Visco, C.; Tzankov, A.; Xu-Monette, Z.Y.; Miranda, R.N.; Tai, Y.C.; Li, Y.; Liu, W.; d'Amore, E.S.G.; Li, Y.; Montes-Moreno, S.; et al. Patients with diffuse large B-cell lymphoma of germinal center origin with BCL2 translocations have poor outcome, irrespective of MYC status: A report from an International DLBCL rituximab-CHOP Consortium Program Study. Haematologica 2013, 98, 255-263. [CrossRef]

66. Seibold, M.; Stühmer, T.; Kremer, N.; Mottok, A.; Scholz, C.-J.; Schlosser, A.; Leich, E.; Holzgrabe, U.; Brünnert, D.; Barrio, S.; et al. RAL GTPases mediate multiple myeloma cell survival and are activated independently of oncogenic RAS. Haematologica 2019. [CrossRef]

67. Chapuy, B.; Stewart, C.; Wood, T.; Dunford, A.; Wienand, K.; Getz, G.; Shipp, M.A. Validation of the Genetically-Defined DLBCL Subtypes and Generation of a Parsimonious Probabilistic Classifier. Blood 2019, 134, 920. [CrossRef]

68. Ruan, J.; Leonard, J.P. Targeting angiogenesis: A novel, rational therapeutic approach for non-Hodgkin lymphoma. Leuk. Lymphoma 2009, 50, 679-681. [CrossRef]

69. Ciavarella, S.; Vegliante, M.C.; Fabbri, M.; De Summa, S.; Melle, F.; Motta, G.; De Iuliis, V.; Opinto, G.; Enjuanes, A.; Rega, S.; et al. Dissection of DLBCL microenvironment provides a gene expression-based predictor of survival applicable to formalin-fixed paraffin-embedded tissue. Ann. Oncol. Off. J. Eur. Soc. Med. Oncol. 2018, 29, 2363-2370. [CrossRef]

70. Kinugasa, Y.; Matsui, T.; Takakura, N. CD44 Expressed on Cancer-Associated Fibroblasts Is a Functional Molecule Supporting the Stemness and Drug Resistance of Malignant Cancer Cells in the Tumor Microenvironment: Tumor Stromal CD44. Stem Cells 2014, 32, 145-156. [CrossRef]

71. Frassanito, M.A.; Desantis, V.; Di Marzo, L.; Craparotta, I.; Beltrame, L.; Marchini, S.; Annese, T.; Visino, F.; Arciuli, M.; Saltarella, I.; et al. Bone marrow fibroblasts overexpress miR-27b and miR-214 in step with multiple myeloma progression, dependent on tumour cell-derived exosomes. J. Pathol. 2019, 247, $241-253$. [CrossRef] 
72. Nicholas, N.S.; Apollonio, B.; Ramsay, A.G. Tumor microenvironment (TME)-driven immune suppression in B cell malignancy. Biochim. Biophys. Acta BBA Mol. Cell Res. 2016, 1863, 471-482. [CrossRef] [PubMed]

73. Hedström, G.; Berglund, M.; Molin, D.; Fischer, M.; Nilsson, G.; Thunberg, U.; Book, M.; Sundström, C.; Rosenquist, R.; Roos, G.; et al. Mast cell infiltration is a favourable prognostic factor in diffuse large B-cell lymphoma. Br. J. Haematol. 2007, 138, 68-71. [CrossRef] [PubMed]

74. Cai, Q.; Liao, H.; Lin, S.; Xia, Y.; Wang, X.; Gao, Y.; Lin, Z.; Lu, J.; Huang, H. High expression of tumor-infiltrating macrophages correlates with poor prognosis in patients with diffuse large B-cell lymphoma. Med. Oncol. 2012, 29, 2317-2322. [CrossRef] [PubMed]

75. Kini, A.R. Angiogenesis in Leukemia and Lymphoma. In Hematopathology in Oncology; Finn, W.G., Peterson, L.C., Eds.; Cancer Treatment and Research; Kluwer Academic Publishers: Boston, MA, USA, 2004; Volume 121, pp. 221-238. ISBN 978-1-4020-7919-1.

76. Ribatti, D.; Nico, B.; Ranieri, G.; Specchia, G.; Vacca, A. The Role of Angiogenesis in Human Non-Hodgkin Lymphomas. Neoplasia 2013, 15, 231-238. [CrossRef]

77. Shain, K.H.; Dalton, W.S.; Tao, J. The tumor microenvironment shapes hallmarks of mature B-cell malignancies. Oncogene 2015, 34, 4673-4682. [CrossRef] [PubMed]

78. Buggy, J.J.; Elias, L. Bruton Tyrosine Kinase (BTK) and Its Role in B-cell Malignancy. Int. Rev. Immunol. 2012, 31, 119-132. [CrossRef]

79. Fornecker, L.-M.; Muller, L.; Bertrand, F.; Paul, N.; Pichot, A.; Herbrecht, R.; Chenard, M.-P.; Mauvieux, L.; Vallat, L.; Bahram, S.; et al. Multi-omics dataset to decipher the complexity of drug resistance in diffuse large B-cell lymphoma. Sci. Rep. 2019, 9, 895. [CrossRef]

80. Di Marzo, L.; Desantis, V.; Solimando, A.G.; Ruggieri, S.; Annese, T.; Nico, B.; Fumarulo, R.; Vacca, A.; Frassanito, M.A. Microenvironment drug resistance in multiple myeloma: Emerging new players. Oncotarget 2016, 7, 60698-60711. [CrossRef]

81. Tomida, A.; Tsuruo, T. Drug resistance mediated by cellular stress response to the microenvironment of solid tumors. Anticancer. Drug Des. 1999, 14, 169-177.

82. Alizadeh, A.A.; Gentles, A.J.; Alencar, A.J.; Liu, C.L.; Kohrt, H.E.; Houot, R.; Goldstein, M.J.; Zhao, S.; Natkunam, Y.; Advani, R.H.; et al. Prediction of survival in diffuse large B-cell lymphoma based on the expression of 2 genes reflecting tumor and microenvironment. Blood 2011, 118, 1350-1358. [CrossRef]

83. Argentiero, A.; De Summa, S.; Di Fonte, R.; Iacobazzi, R.M.; Porcelli, L.; Da Vià, M.; Brunetti, O.; Azzariti, A.; Silvestris, N.; Solimando, A.G. Gene Expression Comparison between the Lymph Node-Positive and -Negative Reveals a Peculiar Immune Microenvironment Signature and a Theranostic Role for WNT Targeting in Pancreatic Ductal Adenocarcinoma: A Pilot Study. Cancers 2019, 11, 942. [CrossRef] [PubMed]

84. Facciabene, A.; Motz, G.T.; Coukos, G. T-regulatory cells: Key players in tumor immune escape and angiogenesis. Cancer Res. 2012, 72, 2162-2171. [CrossRef]

85. Leone, P.; Di Lernia, G.; Solimando, A.G.; Cicco, S.; Saltarella, I.; Lamanuzzi, A.; Ria, R.; Frassanito, M.A.; Ponzoni, M.; Ditonno, P.; et al. Bone marrow endothelial cells sustain a tumor-specific CD8+ T cell subset with suppressive function in myeloma patients. Oncoimmunology 2019, 8, e1486949. [CrossRef] [PubMed]

86. Ribatti, D.; Vacca, A.; Dammacco, F.; English, D. Angiogenesis and Anti-Angiogenesis in Hematological Malignancies. J. Hematother. Stem Cell Res. 2003, 12, 11-22. [CrossRef] [PubMed]

87. Desantis, V.; Frassanito, M.A.; Tamma, R.; Saltarella, I.; Di Marzo, L.; Lamanuzzi, A.; Solimando, A.G.; Ruggieri, S.; Annese, T.; Nico, B.; et al. Rhu-Epo down-regulates pro-tumorigenic activity of cancer-associated fibroblasts in multiple myeloma. Ann. Hematol. 2018, 97, 1251-1258. [CrossRef] [PubMed]

88. Tonia, T.; Mettler, A.; Robert, N.; Schwarzer, G.; Seidenfeld, J.; Weingart, O.; Hyde, C.; Engert, A.; Bohlius, J. Erythropoietin or darbepoetin for patients with cancer. Cochrane Database Syst. Rev. 2012, 12, CD003407. [CrossRef] [PubMed]

89. Suhasini, A.N.; Wang, L.; Holder, K.N.; Lin, A.-P.; Bhatnagar, H.; Kim, S.-W.; Moritz, A.W.; Aguiar, R.C.T. A phosphodiesterase 4B-dependent interplay between tumor cells and the microenvironment regulates angiogenesis in B-cell lymphoma. Leukemia 2016, 30, 617-626. [CrossRef]

90. Serafini, P.; Mgebroff, S.; Noonan, K.; Borrello, I. Myeloid-Derived Suppressor Cells Promote Cross-Tolerance in B-Cell Lymphoma by Expanding Regulatory T Cells. Cancer Res. 2008, 68, 5439-5449. [CrossRef] 
91. Broséus, J.; Mourah, S.; Ramstein, G.; Bernard, S.; Mounier, N.; Cuccuini, W.; Gaulard, P.; Gisselbrecht, C.; Brière, J.; Houlgatte, R.; et al. VEGF121, is predictor for survival in activated B-cell-like diffuse large B-cell lymphoma and is related to an immune response gene signature conserved in cancers. Oncotarget 2017, 8, 90808-90824. [CrossRef]

92. Burger, J.A.; Ghia, P.; Rosenwald, A.; Caligaris-Cappio, F. The microenvironment in mature B-cell malignancies: A target for new treatment strategies. Blood 2009, 114, 3367-3375. [CrossRef]

93. Solimando, A.G.; Da Via', M.C.; Leone, P.; Croci, G.; Borrelli, P.; Tabares Gaviria, P.; Brandl, A.; Di Lernia, G.; Bianchi, F.P.; Tafuri, S.; et al. Adhesion-Mediated Multiple Myeloma (MM) Disease Progression: Junctional Adhesion Molecule a Enhances Angiogenesis and Multiple Myeloma Dissemination and Predicts Poor Survival. Blood 2019, 134, 855. [CrossRef]

94. Pizzi, M.; Boi, M.; Bertoni, F.; Inghirami, G. Emerging therapies provide new opportunities to reshape the multifaceted interactions between the immune system and lymphoma cells. Leukemia 2016, 30, 1805-1815. [CrossRef] [PubMed]

95. Scuto, A.; Kujawski, M.; Kowolik, C.; Krymskaya, L.; Wang, L.; Weiss, L.M.; Digiusto, D.; Yu, H.; Forman, S.; Jove, R. STAT3 inhibition is a therapeutic strategy for ABC-like diffuse large B-cell lymphoma. Cancer Res. 2011, 71, 3182-3188. [CrossRef] [PubMed]

96. Passalidou, E.; Stewart, M.; Trivella, M.; Steers, G.; Pillai, G.; Dogan, A.; Leigh, I.; Hatton, C.; Harris, A.; Gatter, K.; et al. Vascular patterns in reactive lymphoid tissue and in non-Hodgkin's lymphoma. Br. J. Cancer 2003, 88, 553-559. [CrossRef]

97. Cardesa-Salzmann, T.M.; Colomo, L.; Gutierrez, G.; Chan, W.C.; Weisenburger, D.; Climent, F.; Gonzalez-Barca, E.; Mercadal, S.; Arenillas, L.; Serrano, S.; et al. High microvessel density determines a poor outcome in patients with diffuse large B-cell lymphoma treated with rituximab plus chemotherapy. Haematologica 2011, 96, 996-1001. [CrossRef]

98. Woźnialis, N.; Gierej, B.; Popławska, L.; Ziarkiewicz, M.; Wilczek, E.; Kulczycka, E.; Ziarkiewicz-Wróblewska, B. Angiogenesis in CD5-positive Diffuse Large B Cell Lymphoma: A Morphometric Analysis. Adv. Clin. Exp. Med. 2016, 25, 1149-1155. [CrossRef]

99. Shipp, M.A.; Ross, K.N.; Tamayo, P.; Weng, A.P.; Kutok, J.L.; Aguiar, R.C.T.; Gaasenbeek, M.; Angelo, M.; Reich, M.; Pinkus, G.S.; et al. Diffuse large B-cell lymphoma outcome prediction by gene-expression profiling and supervised machine learning. Nat. Med. 2002, 8, 68-74. [CrossRef]

100. Gratzinger, D.; Zhao, S.; Tibshirani, R.J.; Hsi, E.D.; Hans, C.P.; Pohlman, B.; Bast, M.; Avigdor, A.; Schiby, G.; Nagler, A.; et al. Prognostic Significance of VEGF, VEGF Receptors, and Microvessel Density in Diffuse Large B Cell Lymphoma Treated with Anthracycline-Based Chemotherapy. Blood 2007, 110, 53. [CrossRef]

101. Jørgensen, J.M.; Sørensen, F.B.; Bendix, K.; Nielsen, J.L.; Olsen, M.L.; Funder, A.M.D.; D'amore, F. Angiogenesis in non-Hodgkin's lymphoma: Clinico-pathological correlations and prognostic significance in specific subtypes. Leuk. Lymphoma 2007, 48, 584-595. [CrossRef]

102. Jiang, L.; Sun, J.; Quan, L.-N.; Tian, Y.-Y.; Jia, C.-M.; Liu, Z.-Q.; Liu, A.-C. Abnormal vascular endothelial growth factor protein expression may be correlated with poor prognosis in diffuse large B-cell lymphoma: A meta-analysis. J. Cancer Res. Ther. 2016, 12, 605. [CrossRef]

103. Yoon, K.-A.; Kim, M.K.; Eom, H.-S.; Lee, H.; Park, W.S.; Sohn, J.Y.; Kim, M.J.; Kong, S.-Y. Adverse prognostic impact of vascular endothelial growth factor gene polymorphisms in patients with diffuse large B-cell lymphoma. Leuk. Lymphoma 2017, 58, 2677-2682. [CrossRef] [PubMed]

104. Ganjoo, K.N.; Moore, A.M.; Orazi, A.; Sen, J.A.; Johnson, C.S.; An, C.S. The importance of angiogenesis markers in the outcome of patients with diffuse large B cell lymphoma: A retrospective study of 97 patients. J. Cancer Res. Clin. Oncol. 2008, 134, 381-387. [CrossRef] [PubMed]

105. Kim, M.K.; Suh, C.; Chi, H.S.; Cho, H.S.; Bae, Y.K.; Lee, K.H.; Lee, G.-W.; Kim, I.-S.; Eom, H.-S.; Kong, S.-Y.; et al. VEGFA and VEGFR2 genetic polymorphisms and survival in patients with diffuse large B cell lymphoma. Cancer Sci. 2012, 103, 497-503. [CrossRef] [PubMed]

106. Borges, N.M.; do Elias, M.V.; Fook-Alves, V.L.; Andrade, T.A.; de Conti, M.L.; Macedo, M.P.; Begnami, M.D.; Campos, A.H.J.F.M.; Etto, L.Y.; Bortoluzzo, A.B.; et al. Angiomirs expression profiling in diffuse large B-Cell lymphoma. Oncotarget 2016, 7. [CrossRef]

107. Lupino, L.; Perry, T.; Margielewska, S.; Hollows, R.; Ibrahim, M.; Care, M.; Allegood, J.; Tooze, R.; Sabbadini, R.; Reynolds, G.; et al. Sphingosine-1-phosphate signalling drives an angiogenic transcriptional programme in diffuse large B cell lymphoma. Leukemia 2019, 33, 2884-2897. [CrossRef] 
108. Pyne, S.; Pyne, N. Sphingosine 1-phosphate signalling via the endothelial differentiation gene family of G-protein-coupled receptors. Pharmacol. Ther. 2000, 88, 115-131. [CrossRef]

109. Wang, E.S.; Teruya-Feldstein, J.; Wu, Y.; Zhu, Z.; Hicklin, D.J.; Moore, M.A.S. Targeting autocrine and paracrine VEGF receptor pathways inhibits human lymphoma xenografts in vivo. Blood 2004, 104, $2893-2902$. [CrossRef]

110. Aref, S.; Mabed, M.; Zalata, K.; Sakrana, M.; El Askalany, H. The Interplay Between C-Myc Oncogene Expression and Circulating Vascular Endothelial Growth Factor (sVEGF), Its Antagonist Receptor, Soluble Flt-1 in Diffuse Large B Cell Lymphoma (DLBCL): Relationship to Patient Outcome. Leuk. Lymphoma 2004, 45, 499-506. [CrossRef]

111. Stopeck, A.T.; Unger, J.M.; Rimsza, L.M.; Bellamy, W.T.; Iannone, M.; Persky, D.O.; Leblanc, M.; Fisher, R.I.; Miller, T.P. A phase II trial of single agent bevacizumab in patients with relapsed, aggressive non-Hodgkin lymphoma: Southwest oncology group study S0108. Leuk. Lymphoma 2009, 50, 728-735. [CrossRef]

112. Marinaccio, C.; Ingravallo, G.; Gaudio, F.; Perrone, T.; Nico, B.; Maoirano, E.; Specchia, G.; Ribatti, D. Microvascular density, CD68 and tryptase expression in human Diffuse Large B-Cell Lymphoma. Leuk. Res. 2014, 38, 1374-1377. [CrossRef]

113. Marinaccio, C.; Ingravallo, G.; Gaudio, F.; Perrone, T.; Ruggieri, S.; Opinto, G.; Nico, B.; Maiorano, E.; Specchia, G.; Ribatti, D. T cells, mast cells and microvascular density in diffuse large B cell lymphoma. Clin. Exp. Med. 2016, 16, 301-306. [CrossRef] [PubMed]

114. Song, M.-K.; Chung, J.-S.; Sung-Yong, O.; Lee, G.-W.; Kim, S.-G.; Seol, Y.-M.; Shin, H.-J.; Choi, Y.-J.; Cho, G.-J.; Shin, D.-H.; et al. Clinical impact of bulky mass in the patient with primary extranodal diffuse large B cell lymphoma treated with R-CHOP therapy. Ann. Hematol. 2010, 89, 985-991. [CrossRef] [PubMed]

115. Tamma, R.; Ingravallo, G.; Albano, F.; Gaudio, F.; Annese, T.; Ruggieri, S.; Lorusso, L.; Errede, M.; Maiorano, E.; Specchia, G.; et al. STAT-3 RNAscope Determination in Human Diffuse Large B-Cell Lymphoma. Transl. Oncol. 2019, 12, 545-549. [CrossRef] [PubMed]

116. Tamma, R.; Ingravallo, G.; Gaudio, F.; Annese, T.; Albano, F.; Ruggieri, S.; Dicataldo, M.; Maiorano, E.; Specchia, G.; Ribatti, D. STAT3, tumor microenvironment, and microvessel density in diffuse large B cell lymphomas. Leuk. Lymphoma 2020, 61, 567-574. [CrossRef] [PubMed]

117. Sircar, A.; Chowdhury, S.M.; Hart, A.; Bell, W.C.; Singh, S.; Sehgal, L.; Epperla, N. Impact and Intricacies of Bone Marrow Microenvironment in B-cell Lymphomas: From Biology to Therapy. Int. J. Mol. Sci. 2020, 21, 904. [CrossRef]

118. De Charette, M.; Houot, R. Hide or defend, the two strategies of lymphoma immune evasion: Potential implications for immunotherapy. Haematologica 2018, 103, 1256-1268. [CrossRef] [PubMed]

119. Miao, X.; Wu, Y.; Wang, Y.; Zhu, X.; Yin, H.; He, Y.; Li, C.; Liu, Y.; Lu, X.; Chen, Y.; et al. Y-box-binding protein-1 (YB-1) promotes cell proliferation, adhesion and drug resistance in diffuse large B-cell lymphoma. Exp. Cell Res. 2016, 346, 157-166. [CrossRef]

120. Huang, X.; Bai, X.; Cao, Y.; Wu, J.; Huang, M.; Tang, D.; Tao, S.; Zhu, T.; Liu, Y.; Yang, Y.; et al. Lymphoma endothelium preferentially expresses Tim-3 and facilitates the progression of lymphoma by mediating immune evasion. J. Exp. Med. 2010, 207, 505-520. [CrossRef]

121. Edwards, J.P.; Zhang, X.; Mosser, D.M. The expression of heparin-binding epidermal growth factor-like growth factor by regulatory macrophages. J. Immunol. Baltim. Md 1950 2009, 182, 1929-1939. [CrossRef]

122. Rao, L.; Giannico, D.; Leone, P.; Solimando, A.G.; Maiorano, E.; Caporusso, C.; Duda, L.; Tamma, R.; Mallamaci, R.; Susca, N.; et al. HB-EGF-EGFR Signaling in Bone Marrow Endothelial Cells Mediates Angiogenesis Associated with Multiple Myeloma. Cancers 2020, 12, 173. [CrossRef]

123. Tjin, E.P.M.; Groen, R.W.J.; Vogelzang, I.; Derksen, P.W.B.; Klok, M.D.; Meijer, H.P.; van Eeden, S.; Pals, S.T.; Spaargaren, M. Functional analysis of HGF/MET signaling and aberrant HGF-activator expression in diffuse large B-cell lymphoma. Blood 2006, 107, 760-768. [CrossRef]

124. Moschetta, M.; Basile, A.; Ferrucci, A.; Frassanito, M.A.; Rao, L.; Ria, R.; Solimando, A.G.; Giuliani, N.; Boccarelli, A.; Fumarola, F.; et al. Novel targeting of phospho-cMET overcomes drug resistance and induces antitumor activity in multiple myeloma. Clin. Cancer Res. Off. J. Am. Assoc. Cancer Res. 2013, 19, 4371-4382. [CrossRef] [PubMed] 
125. Ferrucci, A.; Moschetta, M.; Frassanito, M.A.; Berardi, S.; Catacchio, I.; Ria, R.; Racanelli, V.; Caivano, A.; Solimando, A.G.; Vergara, D.; et al. A HGF/cMET autocrine loop is operative in multiple myeloma bone marrow endothelial cells and may represent a novel therapeutic target. Clin. Cancer Res. Off. J. Am. Assoc. Cancer Res. 2014, 20, 5796-5807. [CrossRef] [PubMed]

126. Rao, L.; De Veirman, K.; Giannico, D.; Saltarella, I.; Desantis, V.; Frassanito, M.A.; Solimando, A.G.; Ribatti, D.; Prete, M.; Harstrick, A.; et al. Targeting angiogenesis in multiple myeloma by the VEGF and HGF blocking DARPin ${ }^{\circledR}$ protein MP0250: A preclinical study. Oncotarget 2018, 9, 13366-13381. [CrossRef] [PubMed]

127. Siegler, E.; Li, S.; Kim, Y.J.; Wang, P. Designed Ankyrin Repeat Proteins as Her2 Targeting Domains in Chimeric Antigen Receptor-Engineered T Cells. Hum. Gene Ther. 2017, 28, 726-736. [CrossRef] [PubMed]

128. Xu, P.-P.; Sun, Y.-F.; Fang, Y.; Song, Q.; Yan, Z.-X.; Chen, Y.; Jiang, X.-F.; Fei, X.-C.; Zhao, Y.; Leboeuf, C.; et al. JAM-A overexpression is related to disease progression in diffuse large B-cell lymphoma and downregulated by lenalidomide. Sci. Rep. 2017, 7, 7433. [CrossRef] [PubMed]

129. Yu, W.; Si, M.; Li, L.; He, P.; Fan, Z.; Zhang, Q.; Jiao, X. Biomarkers Reflecting the Destruction of the Blood-Brain Barrier Are Valuable in Predicting the Risk of Lymphomas with Central Nervous System Involvement. Onco Targets Ther. 2019, 12, 9505-9512. [CrossRef]

130. Karar, J.; Maity, A. PI3K/AKT/mTOR Pathway in Angiogenesis. Front. Mol. Neurosci. 2011, 4, 51. [CrossRef]

131. Goodman, A.M.; Choi, M.; Wieduwilt, M.; Mulroney, C.; Costello, C.; Frampton, G.; Miller, V.; Kurzrock, R. Next-Generation Sequencing Reveals Potentially Actionable Alterations in the Majority of Patients with Lymphoid Malignancies. JCO Precis. Oncol. 2017, 1-13. [CrossRef]

132. Todorovic Balint, M.; Jelicic, J.; Mihaljevic, B.; Kostic, J.; Stanic, B.; Balint, B.; Pejanovic, N.; Lucic, B.; Tosic, N.; Marjanovic, I.; et al. Gene Mutation Profiles in Primary Diffuse Large B Cell Lymphoma of Central Nervous System: Next Generation Sequencing Analyses. Int. J. Mol. Sci. 2016, 17, 683. [CrossRef]

133. Vaqué, J.P.; Martínez, N.; Batlle-López, A.; Pérez, C.; Montes-Moreno, S.; Sánchez-Beato, M.; Piris, M.A. B-cell lymphoma mutations: Improving diagnostics and enabling targeted therapies. Haematologica 2014, 99, 222-231. [CrossRef] [PubMed]

134. Lee, J.-H.S.; Vo, T.-T.; Fruman, D.A. Targeting mTOR for the treatment of B cell malignancies. Br. J. Clin. Pharmacol. 2016, 82, 1213-1228. [CrossRef] [PubMed]

135. Da Vià, M.C.; Solimando, A.G.; Garitano-Trojaola, A.; Barrio, S.; Munawar, U.; Strifler, S.; Haertle, L.; Rhodes, N.; Teufel, E.; Vogt, C.; et al. CIC Mutation as a Molecular Mechanism of Acquired Resistance to Combined BRAF-MEK Inhibition in Extramedullary Multiple Myeloma with Central Nervous System Involvement. Oncologist 2020, 25, 112-118. [CrossRef]

136. Holderfield, M.; Deuker, M.M.; McCormick, F.; McMahon, M. Targeting RAF kinases for cancer therapy: BRAF-mutated melanoma and beyond. Nat. Rev. Cancer 2014, 14, 455-467. [CrossRef] [PubMed]

137. Lamanuzzi, A.; Saltarella, I.; Desantis, V.; Frassanito, M.A.; Leone, P.; Racanelli, V.; Nico, B.; Ribatti, D.; Ditonno, P.; Prete, M.; et al. Inhibition of mTOR complex 2 restrains tumor angiogenesis in multiple myeloma. Oncotarget 2018, 9, 20563-20577. [CrossRef] [PubMed]

138. Solimando, A.G.; Brandl, A.; Mattenheimer, K.; Graf, C.; Ritz, M.; Ruckdeschel, A.; Stühmer, T.; Mokhtari, Z.; Rudelius, M.; Dotterweich, J.; et al. JAM-A as a prognostic factor and new therapeutic target in multiple myeloma. Leukemia 2018, 32, 736-743. [CrossRef]

139. Solimando, A.G.; Da Via', M.C.; Borrelli, P.; Leone, P.; Di Lernia, G.; Tabares Gaviria, P.; Brandl, A.; Pedone, G.L.; Rauert-Wunderlich, H.; Lapa, C.; et al. Central Function for JAM-a in Multiple Myeloma Patients with Extramedullary Disease. Blood 2018, 132, 4455. [CrossRef]

140. Mielcarek, M.; Sperling, C.; Shrappe, M.; Meyer, U.; Riehm, H.; Ludwig, W.-D. Expression of intercellular adhesion molecule 1 (ICAM-1) in childhood acute lymphoblastic leukaemia: Correlation with clinical features and outcome. Br. J. Haematol. 1997, 96, 301-307. [CrossRef]

141. Horstmann, W.G.; Timens, W. Lack of adhesion molecules in testicular diffuse centroblastic and immunoblastic B cell lymphomas as a contributory factor in malignant behaviour. Virchows Arch. 1996, 429, 83-90. [CrossRef]

142. Da Via', M.C.; Solimando, A.G.; Garitano-Trojaola, A.; Barrio, S.; Rodhes, N.; Strifler, S.; Teufel, E.; Lapa, C.; Einsele, H.; Beilhack, A.; et al. CIC-Mutation As a Potential Molecular Mechanism of Acquired Resistance to Combined BRAF/MEK Inhibition in CNS Multiple Myeloma. Blood 2018, 132, 3181. [CrossRef]

143. Pasqualucci, L. The genetic basis of diffuse large B-cell lymphoma. Curr. Opin. Hematol. 2013, 20, 336-344. [CrossRef] [PubMed] 
144. Stopeck, A.T.; Gessner, A.; Miller, T.P.; Hersh, E.M.; Johnson, C.S.; Cui, H.; Frutiger, Y.; Grogan, T.M. Loss of B7.2 (CD86) and intracellular adhesion molecule 1 (CD54) expression is associated with decreased tumor-infiltrating T lymphocytes in diffuse B-cell large-cell lymphoma. Clin. Cancer Res. Off. J. Am. Assoc. Cancer Res. 2000, 6, 3904-3909.

145. Terol, M.J.; Tormo, M.; Martinez-Climent, J.A.; Marugan, I.; Benet, I.; Ferrandez, A.; Teruel, A.; Ferrer, R.; García-Conde, J. Soluble intercellular adhesion molecule-1 (s-ICAM-1/s-CD54) in diffuse large B-cell lymphoma: Association with clinical characteristics and outcome. Ann. Oncol. Off. J. Eur. Soc. Med. Oncol. 2003, 14, 467-474. [CrossRef] [PubMed]

146. Zhang, L.-H.; Kosek, J.; Wang, M.; Heise, C.; Schafer, P.H.; Chopra, R. Lenalidomide efficacy in activated B-cell-like subtype diffuse large B-cell lymphoma is dependent upon IRF4 and cereblon expression. Br. J. Haematol. 2013, 160, 487-502. [CrossRef]

147. Gascoyne, D.M.; Banham, A.H. The significance of FOXP1 in diffuse large B-cell lymphoma. Leuk. Lymphoma 2017, 58, 1037-1051. [CrossRef]

148. Solimando, A.; Brandl, A.; Katharina, M.; Graf, C.; Ritz, M.; Ruckdeschel, A.; Stühmer, T.; Rudelius, M.; Frassanito, M.A.; Andreas, R.; et al. JAM-A as a Prognostic Factor and New Therapeutic Target in Multiple Myeloma. Blood 2016, 128, 307. [CrossRef]

149. Ebnet, K. Junctional Adhesion Molecules (JAMs): Cell Adhesion Receptors With Pleiotropic Functions in Cell Physiology and Development. Physiol. Rev. 2017, 97, 1529-1554. [CrossRef]

150. Koenen, R.R.; Pruessmeyer, J.; Soehnlein, O.; Fraemohs, L.; Zernecke, A.; Schwarz, N.; Reiss, K.; Sarabi, A.; Lindbom, L.; Hackeng, T.M.; et al. Regulated release and functional modulation of junctional adhesion molecule A by disintegrin metalloproteinases. Blood 2009, 113, 4799-4809. [CrossRef]

151. Leech, A.O.; Cruz, R.G.B.; Hill, A.D.K.; Hopkins, A.M. Paradigms lost-an emerging role for over-expression of tight junction adhesion proteins in cancer pathogenesis. Ann. Transl. Med. 2015, 3, 184. [CrossRef]

152. Zhao, C.; Lu, F.; Chen, H.; Zhao, X.; Sun, J.; Chen, H. Dysregulation of JAM-A plays an important role in human tumor progression. Int. J. Clin. Exp. Pathol. 2014, 7, 7242-7248.

153. Scheller, J.; Chalaris, A.; Garbers, C.; Rose-John, S. ADAM17: A molecular switch to control inflammation and tissue regeneration. Trends Immunol. 2011, 32, 380-387. [CrossRef]

154. Katz, E.; Deehan, M.R.; Seatter, S.; Lord, C.; Sturrock, R.D.; Harnett, M.M. B cell receptor-stimulated mitochondrial phospholipase A2 activation and resultant disruption of mitochondrial membrane potential correlate with the induction of apoptosis in WEHI-231 B cells. J. Immunol. Baltim. Md 1950 2001, 166, 137-147. [CrossRef]

155. Jridi, I.; Catacchio, I.; Majdoub, H.; Shahbazzadeh, D.; El Ayeb, M.; Frassanito, M.A.; Solimando, A.G.; Ribatti, D.; Vacca, A.; Borchani, L. The small subunit of Hemilipin2, a new heterodimeric phospholipase A2 from Hemiscorpius lepturus scorpion venom, mediates the antiangiogenic effect of the whole protein. Toxicon Off. J. Int. Soc. Toxinol. 2017, 126, 38-46. [CrossRef]

156. Upadhyay, R.; Hammerich, L.; Peng, P.; Brown, B.; Merad, M.; Brody, J.D. Lymphoma: Immune evasion strategies. Cancers 2015, 7, 736-762. [CrossRef]

157. Tripodo, C.; Sangaletti, S.; Piccaluga, P.P.; Prakash, S.; Franco, G.; Borrello, I.; Orazi, A.; Colombo, M.P.; Pileri, S.A. The bone marrow stroma in hematological neoplasms-a guilty bystander. Nat. Rev. Clin. Oncol. 2011, 8, 456-466. [CrossRef]

158. Rafii, S.; Lyden, D.; Benezra, R.; Hattori, K.; Heissig, B. Vascular and haematopoietic stem cells: Novel targets for anti-angiogenesis therapy? Nat. Rev. Cancer 2002, 2, 826-835. [CrossRef]

159. Grunewald, M.; Avraham, I.; Dor, Y.; Bachar-Lustig, E.; Itin, A.; Jung, S.; Yung, S.; Chimenti, S.; Landsman, L.; Abramovitch, R.; et al. VEGF-induced adult neovascularization: Recruitment, retention, and role of accessory cells. Cell 2006, 124, 175-189. [CrossRef]

160. Seymour, J.F.; Pfreundschuh, M.; Trneny, M.; Sehn, L.H.; Catalano, J.; Csinady, E.; Moore, N.; Coiffier, B. $\mathrm{R}-\mathrm{CHOP}$ with or without bevacizumab in patients with previously untreated diffuse large B-cell lymphoma: Final MAIN study outcomes. Haematologica 2014, 99, 1343-1349. [CrossRef]

161. Jiang, L.; Li, N. B-cell non-Hodgkin lymphoma: Importance of angiogenesis and antiangiogenic therapy. Angiogenesis 2020. [CrossRef]

162. Joyce, J.A.; Fearon, D.T. T cell exclusion, immune privilege, and the tumor microenvironment. Science 2015, 348, 74-80. [CrossRef] 
163. Galon, J.; Bruni, D. Approaches to treat immune hot, altered and cold tumours with combination immunotherapies. Nat. Rev. Drug Discov. 2019, 18, 197-218. [CrossRef]

164. Antonio, G.; Oronzo, B.; Vito, L.; Angela, C.; Antonel-la, A.; Roberto, C.; Giovanni, S.A.; Antonella, L. Immune system and bone microenvironment: Rationale for targeted cancer therapies. Oncotarget 2020, 11. [CrossRef]

165. Fukumura, D.; Kloepper, J.; Amoozgar, Z.; Duda, D.G.; Jain, R.K. Enhancing cancer immunotherapy using antiangiogenics: Opportunities and challenges. Nat. Rev. Clin. Oncol. 2018, 15, 325-340. [CrossRef] [PubMed]

166. Compagno, N.; Cinetto, F.; Semenzato, G.; Agostini, C. Subcutaneous immunoglobulin in lymphoproliferative disorders and rituximab-related secondary hypogammaglobulinemia: A single-center experience in 61 patients. Haematologica 2014, 99, 1101-1106. [CrossRef] [PubMed]

167. Vacca, A.; Melaccio, A.; Sportelli, A.; Solimando, A.G.; Dammacco, F.; Ria, R. Subcutaneous immunoglobulins in patients with multiple myeloma and secondary hypogammaglobulinemia: A randomized trial. Clin. Immunol. Orlando Fl. 2018, 191, 110-115. [CrossRef] [PubMed]

168. Ma, X.; Li, L.; Zhang, L.; Fu, X.; Li, X.; Wang, X.; Wu, J.; Sun, Z.; Zhang, X.; Feng, X.; et al. Apatinib in Patients with Relapsed or Refractory Diffuse Large B Cell Lymphoma: A Phase II, Open-Label, Single-Arm, Prospective Study. Drug Des. Devel. Ther. 2020, 14, 275-284. [CrossRef] [PubMed]

169. Wang, Y.; Deng, M.; Chen, Q.; Li, Y.; Guo, X.; Shi, P.; He, L.; Xie, S.; Yu, L.; Zhang, H.; et al. Apatinib exerts anti-tumor activity to non-Hodgkin lymphoma by inhibition of the Ras pathway. Eur. J. Pharmacol. 2019, 843, 145-153. [CrossRef] [PubMed]

170. Pfreundschuh, M.; Kloess, M.; Schmits, R.; Zeynalova, S.; Lengfelder, E.; Franke, A.; Steinhauer, H.; Reiser, M.; Clemens, M.; Nickenig, C.; et al. Six, Not Eight Cycles of Bi-Weekly CHOP with Rituximab (R-CHOP-14) Is the Preferred Treatment for Elderly Patients with Diffuse Large B-Cell Lymphoma (DLBCL): Results of the RICOVER-60 Trial of the German High-Grade Non-Hodgkin Lymphoma Study Group (DSHNHL). Blood 2005, 106, 13. [CrossRef]

(C) 2020 by the authors. Licensee MDPI, Basel, Switzerland. This article is an open access article distributed under the terms and conditions of the Creative Commons Attribution (CC BY) license (http://creativecommons.org/licenses/by/4.0/). 